\title{
AS CULTURAS LIBERAL E DEMOCRÁTICA DE PROTEÇÃO DOS DIREITOS INDIVIDUAIS NO CONSTITUCIONALISMO CLÁSSICO: uma breve análise dos modelos britânico, francês e norte-americano / THE CULTURES LIBERAL AND DEMOCRATIC OF PROTECTION OF INDIVIDUAL RIGHTS IN CLASSIC CONSTITUTIONALISM: a brief analysis of British, French and American models *
}

\begin{abstract}
RESUMO
O presente artigo tem como objetivo analisar a evolução de um conceito antigo para um conceito moderno de Constituição, e, especialmente, a construção de desenhos institucionais paradigmáticos e das teorias políticas a eles subjacentes no que toca à proteção dos direitos fundamentais. Inicialmente será delineado, à luz da teoria de John Locke e da experiência político-constitucional inglesa, um modelo que privilegia o ideal constitucionalista em detrimento do democrático, na medida em que a ênfase recairá na tutela de direitos fundamentais intangíveis ao processo político. Em seguida, com lastro no Estado de Direito Legalista que prevaleceu na Europa Continental das revoluções burguesas até o segundo pósguerra, será construído um modelo de proteção dos direitos fundamentais que se caracteriza pelo primado do ideal democrático sobre o constitucionalista, já que o Parlamento recém dotado de legitimidade democrática não encontrará limites substantivos para a definição do conteúdo dos direitos fundamentais. Por outro lado, será exposta a tese de que o modelo norteamericano de supremacia da Constituição e de controle de constitucionalidade tende a equilibrar os ideais constitucionalista e democrático. Por fim tal assertiva será contextualizada em face das Constituições que integram o neoconstitucionalismo.
\end{abstract}

PALAVRAS-CHAVE: Histórico do Constitucionalismo. Liberalismo. Democracia. Direitos Fundamentais. Desenhos Institucionais.

\begin{abstract}
This paper aims to analyse the evolution of an ancient concept of Constitution to a modern one, and, specially, the development of institutional arrangements and theirs political theories in the light of the protection of the fundamental rights. Initially, it will be described, in the light of Locke's theory and the British's political experience, a model that favours the liberal ideal in prejudice of the democratic one, because it considers the fundamental rights immune to the political process. Later, based on the "legalistic state" that was typical in Europe until the second world war, it will be draw a model that emphasizes the democratic ideal, because it didn't see any material limits to the Parliament's power to define the content
\end{abstract}


of the fundamental rights. By the other side, in the last section will be developed the central thesis of the paper, that consists in the assertion that American model of supremacy of the Constitution and judicial review is designed in order to harmonize the liberal and the democratic ideals. Finally, this thesis will be put in the context of the neoconstitucionalism's Constitutions.

KEYWORDS: The History of Constitutionalism. Liberalism. Democracy. Fundamental Rights. Institutional Design.

\section{Notas introdutórias}

Da leitura das Declarações de Direitos geradas pelas Revoluções Gloriosa, Francesa e Americana (Bill of Rights: Inglaterra, 1689; Declaração Universal dos Direitos do Homem e do Cidadão: França, 1789; Declaração de Direitos da Virgínia e as dez primeiras emendas à Constituição dos EUA, 1787 e 1791), infere-se, no que concerne ao fundamento dos direitos individuais, uma forte confluência na adoção da perspectiva jusnaturalista, e, no tocante ao seu conteúdo, uma uniformidade na incorporação, basicamente, dos valores da liberdade, vida, integridade física, igualdade formal e propriedade. Como principais corolários dos referidos valores, cite-se, v.g.: (i) a igualdade perante a lei, que representava o fim das sociedades divididas em estamentos e do pluralismo de ordens jurídicas existentes da Idade Média; (ii) leis gerais, abstratas e irretroativas, que, segundo essa perspectiva, garantiriam um tratamento impessoal dos cidadãos; (iii) a liberdade religiosa, que se prenunciava desde a Reforma Protestante; (iv) a tutela jurídica da propriedade; (v) garantias de caráter processual, tais como, o devido processo legal e seus consectários, que têm natureza instrumental em relação aos referidos valores; e (vi) as diversas manifestações da liberdade, v.g.: liberdade de ir e vir, de expressão, de manifestação do pensamento, de reunião, de desempenho de profissão e atividades econômicas, etc.

Tais garantias se referem aos chamados direitos de primeira geração, os quais, em regra, estruturam-se sob a forma de direitos de defesa, na medida em que investem os indivíduos da prerrogativa de exigirem do Estado o cumprimento de prestações negativas, isto é, um non facere, uma abstenção. Nítido que tais direitos preservam uma esfera de atuação individual infensa a ingerências estatais, em cujo âmbito, portanto, deve prevalecer a liberdade individual em detrimento da coerção estatal. 
Embora ingleses, franceses e norte-americanos tenham se utilizado do potencial explosivo da afirmação da pré-estatalidade e da auto-evidência dos direitos naturais para questionarem a legitimidade dos regimes contra os quais se opunham, convém sublinhar que, após a poeira revolucionária ter baixado, Inglaterra, ${ }^{1}$ França e EUA adotaram instituições e concepções políticas substancialmente distintas com o escopo de tutelar concretamente as liberdades civis. O objetivo do presente artigo é o de analisar a propensão destes arranjos institucionais paradigmáticos - e das teorias políticas a eles subjacentes - em enfatizar os ideais constitucionalista e democrático, é dizer, a limitação do poder com a finalidade de proteger o indivíduo e a afirmação do poder de autodeterminação do povo, tendo-se em mira os mecanismos disponibilizados à identificação e à tutela dos direitos individuais. Antes, porém, cumpre analisar, brevemente, a evolução de um conceito "antigo" de constituição para um conceito "moderno", pois, somente com a afirmação do último estarão presentes os elementos necessários ao delineamento dos direitos individuais tal qual hoje os conhecemos.

\section{A Constituição mista medieval e a Constituição dos modernos}

Muito embora se reconheça que idéias nucleares à noção de direitos individuais, quais sejam a igualdade entre os homens e a sua dignidade intrínseca, têm origens remotíssimas, como na filosofia estóica e cristã, ${ }^{2}$ vale ressaltar que só há de falar-se em direitos individuais em uma acepção moderna com as revoluções burguesas, na medida em que, apenas a partir de então se afirma a noção de que os indivíduos, independentemente da sua posição social, possuem iguais direitos naturais, oponíveis ao Estado e adquiridos pelo só-fato da sua condição humana (direitos do homem, droits de l'homme, Menschenrechte, the rights of man). Tais

\footnotetext{
* Este artigo é dedicado à Iza Jotta, minha querida avó, por todo o apoio e amor que, em nenhum momento da minha vida, deixou de me dar.

** Procurador do Município do Rio de Janeiro. Mestre em Direito Público pela UERJ, Coordenador do Núcleo de Estudos de Direito Constitucional da PGM/RJ, e Professor de Direito Constitucional da EMERJ, da UERJ (2005/2006), do IBMEC (Direitos Humanos), do Praetorium, do CEJ e da ESAP.

${ }^{1}$ Falta, entretanto, na Inglaterra, toda a carga contra o passado que marca, por exemplo, o movimento revolucionário francês. Com efeito, na Inglaterra verificou-se uma lenta e gradual passagem de uma sociedade estamental para um Estado constitucional, com pequenos interlúdios de exercício absoluto do poder. Assim, o jusnaturalismo ali empregado, com forte influência de John Locke, assume um caráter mais de garantia do que de ruptura. Ver, a propósito, a seção três.

${ }^{2}$ Ver COMPARATTO, Fábio Konder. A Afirmação histórica dos direitos humanos. 2 ed. São Paulo: Ed. Saraiva, 2001.
} 
direitos não se assemelham aos direitos estamentais, que, por se referirem, não a indivíduos isolada e abstratamente considerados, mas insertos em determinada comunidade (v.g.: segmento social ou territorial - estamento, feudo, cidade, aldeia, etc.), assumiam uma estruturação corporativa. Assim, embora prerrogativas insertas em pactos firmados entre o Rei e determinados estamentos, como a Magna Carta de 1215, se destinassem à limitação do poder, faltava-lhes o atributo da generalidade da sua titularidade, bem como a premissa antropocêntrica que só se consolidará na teoria política com o advento do pensamento contratualista e do liberalismo. ${ }^{3}$

Neste ponto, vale destacar que os referidos documentos (Constituições mistas medievais) se consubstanciavam em "acordos" firmados entre os estamentos que compunham a sociedade, veiculando um grande projeto de conciliação social e política, capaz de disciplinar as funções do governante, da aristocracia e do povo, forças estas que, em virtude do caráter misto da Carta, reconheciam-se reciprocamente como componentes da mesma realidade política. Tratava-se, portanto, de Constituição que não veiculava vontade de instituir determinado governo, mas que retratava o equilíbrio obtido entre as forças atuantes na sociedade, integrantes de uma realidade política já formada, em cujo âmbito ainda não se verificava o monopólio estatal do poder de império, mas o seu fracionamento numa complexa teia de estamentos sociais. ${ }^{4}$

É bem de ver que tais Constituições exerceram a notável função - no mais das vezes, a mera pretensão, com a exceção honrosa da Inglaterra - de equilibrar os poderes políticos durante a Idade Média, associando-se à imagem da monarquia limitada, porquanto os pactos nela contidos destinavam-se a distinguir os poderes próprios e específicos do Rei (v.g.: declarar guerra e paz, firmar alianças internacionais, nomear autoridades, etc.) das prerrogativas cujo exercício estava condicionado ao consentimento do Parlamento (v.g.: impor tributos, administrar os bens públicos, etc.), buscando evitar um elastecimento desmedido das prerrogativas régias em detrimento das parlamentares, e vice-versa.

\footnotetext{
${ }^{3}$ V. PECES-BARBA MARTINEZ, Gregório. Curso de Derechos Fundamentales - Teoría General. Madrid: Universidad Carlos III, 1999, p. 105 e 114; ANDRADE, José Carlos Vieira de. Os Direitos Fundamentais na Constituição Portuguesa de 1976. 2 ed. Coimbra: Ed. Almedina, 2001, p. 14/15.

${ }^{4}$ FIORAVANTI. Maurizio. Constituición. De la antiguedad a nuestros días. Madrid: Editorial Trotta, 2001, p. 55 e 63.
} 
A especificação das "atribuições" do Rei e do Parlamento evidencia que a busca de um equilíbrio entre as forças sociais se refletia no domínio específico das instituições políticas, constituindo, a doutrina das Constituições mistas medievais, importantíssimo antecedente histórico do ideal constitucionalista de limitação do poder com fins de garantia do indivíduo e, mais precisamente, da noção de freios e contrapesos entre os órgãos do Estado, de maneira a que nenhum deles ostente um poder absoluto. ${ }^{5}$

Nada obstante, tais documentos não se ajustam ao conceito moderno de Constituição, pertencendo à família das "Constituições dos antigos" ou pré-modernas, especialmente por se referirem a sociedades estamentais, cuja pluralidade de poderes políticos naturais, insubordinada a qualquer tentativa de síntese, incompatibiliza-se com a idéia ascendente de soberania. Isto porque o caráter absoluto da soberania - referente não à ausência de limites, ante a superioridade do direito natural sobre o direito positivo, mas à sua natureza una e indivisível tornava-a insuscetível de qualquer forma de compartilhamento com outros poderes. ${ }^{6}$ Note-se que a concentração do poder político implicada no conceito de soberania, tributária, originariamente, da pretensão absolutista de conter a anarquia que a Constituição mista gerara, ao convolar-se na vontade que dá origem às Constituições modernas (soberania popular, com a alteração do monarca pelo povo em sua titularidade), coloca uma pá de cal no modelo de constitucionalismo anterior, porquanto se consubstancia em pressuposto frontalmente contrário à fragmentação do poder político presente na idade Média.

Ademais, o contratualismo, enquanto teoria e fato histórico que conduz ao constitucionalismo moderno, consiste em antítese radical da teoria política prevalecente na Idade Média. Com efeito, no medievo esposou-se uma concepção organicista da sociedade e do Estado, caracterizada (i) por considerar a sociedade um fato natural, já que o homem seria um “animal político e social”, não se concebendo que possa viver fora da sociedade civil, i.e., no

\footnotetext{
${ }^{5}$ Parece confirmar tais assertivas a circunstância de, respectivamente, (i) os opositores do regime absolutista (p.ex.: huguenotes nas guerras religiosas ocorridas na França na segunda metade do século XVI, e, especialmente os defensores das prerrogativas parlamentares na Inglaterra dos séculos XVI e XVII) terem se utilizado dos pactos firmados com o Rei para questionar a legitimidade de atos do monarca que se desviassem da repartição de poderes neles reconhecida, e (ii) Montesquieu ter, confessadamente, inspirado a sua concepção de separação de poderes na ancient constitution inglesa - sem dúvida alguma, onde a noção de Constituição mista melhor se desenvolveu

${ }^{6}$ Segundo a formulação clássica de Bodin, além da índole absoluta, a soberania apresenta a característica da perpetuidade ou da originariedade, à vista de cuidar-se de poder cuja legitimidade busca-se em si próprio, do que decorre não ser fruto de delegação e não se sujeitar à revogação. V. BODIN, Jean. I sei libri dello Stato, apud FIORAVANTI, Maurizio. op. cit., p. 72 e ss.
} 
Estado de Natureza; (ii) o poder uma função social necessária, fruto de desígnios divinos ou de um conjunto de pactos imemoriais; e (ii) pela analogia da sociedade ao corpo humano: cada indivíduo não seria apenas parte do todo, mas, assim como um órgão, cumpriria uma função especial na vida da sociedade, equiparada, portanto, a um organismo vivo. ${ }^{7}$

Já o contratualismo, por fundar o poder político em um contrato firmado entre indivíduos livres e iguais que marca a passagem do Estado de Natureza para o Estado Social, vincula a legitimidade política ao consentimento dos indivíduos. Portanto, o Estado e o governo, antes de realidades sociais necessárias, revelam-se fruto da vontade do povo, de uma construção artificial que confere ao povo o poder de fundar um Estado, de estabelecer uma forma específica de organização coletiva. Compara-se, portanto, o Estado a algo que é criado pela inteligência humana, como, por exemplo, a uma máquina. ${ }^{8}$ Evidentemente que uma tal teoria política se encontra ligada a uma visão de sociedade radicalmente distinta da medieval: à vinculação da fundamentação do poder político à história e a motivos teológicos opõe-se a busca de legitimação racional do poder através do direito; à divisão da sociedade em estamentos opõem-se a igualdade e a liberdade naturais do indivíduo; à uma perspectiva coletivista opõe-se um modelo individualista, colocando-se, no centro da associação política, indivíduos isoladamente considerados em substituição ao povo concebido como unidade orgânica.

Quanto ao último aspecto, convém destacar que liberalismo e contratualismo comungam de uma visão individualista acerca da origem do poder político, revelando que o irromper do Estado moderno traz consigo uma cisão profunda de cosmovisões, visto que se deixou de ver o exercício do poder político segundo a perspectiva do soberano (ex parte principis), passando-se à do indivíduo (ex parte populi). ${ }^{9}$ Como corolário do exposto, esse momento histórico se consubstanciou em uma ponte entre concepções organicistas e

\footnotetext{
${ }^{7}$ MATTEUCCI, Nicola. Contratualismo. Dicionário de Política. vol. 1, 12 ed. BOBBIO, Norberto et. Al. Brasília: LGE ed. e UnB ed., p. 272/283.

${ }^{8}$ MATTEUCCI, Nicola. Op. cit.

${ }^{9}$ LAFER, Celso. A Reconstrução dos Direitos Humanos - Um diálogo com o pensamento de Hannah Arendt. São Paulo: Companhia das Letras, 1988, p. 125/127; SARMENTO, Daniel. Direitos Fundamentais e Relações Privadas. Rio de Janeiro: Lumen Iuris editora, 2004, p. 22.
} 
individualistas, na medida em que o indivíduo, e não mais a sociedade como um organismo, passou a gozar de uma primazia axiológica. ${ }^{10}$

Há, contudo, clara divergência na tradição contratualista no que concerne à natureza das Constituições e à forma de atuação do poder soberano. De fato, com a superação da Constituição dos antigos pela afirmação das premissas da igualdade e da liberdade naturais e pela fundamentação do poder político no consentimento do povo, duas visões acerca da Constituição dos Modernos, decorrentes de distintas configurações dos modelos contratualistas, contrapunham-se: a absorção do conceito de Constituição pelo de soberania (Hobbes e Rousseau), visto que a lei fundamental restringir-se-ia ao dever de submissão incondicional dos indivíduos ao poder originário, perpétuo e essencialmente livre do soberano, seja ele monarca, Assembléia (Hobbes), ou o povo (Rousseau); e uma concepção, por assim dizer, de matiz liberal, que busca incorporar a tradição do governo moderado e equilibrado à Constituição dos Modernos, compatibilizando a teoria do contrato social com a pretensão constitucionalista de equilibrar e limitar os poderes com a finalidade de proteger os indivíduos. Em virtude do pioneirismo e da importância da sua obra, pode-se afirmar que o principal teórico na construção da referida concepção foi John Locke, em seus clássicos Dois Tratados sobre o Governo. ${ }^{12}$

\footnotetext{
${ }^{10}$ Esclarece Bobbio que: "O que une a doutrina dos direitos do homem e o contratualismo é a comum concepção individualista da sociedade, a concepção segundo a qual primeiro existe o indivíduo singular com seus interesses e carências, que tomam a forma de direitos em virtude da assunção de uma hipotética lei da natureza, e depois a sociedade, e não vice-versa como sustenta o organicismo em todas as suas formas, segundo o qual a sociedade é anterior aos indivíduos ou, conforme a fórmula aristotélica destinada a ter êxito ao longo dos séculos, o todo é anterior às partes. (...)

Sem essa revolução copernicana, à base da qual o problema do Estado passou a ser visto não mais da parte do poder soberano, mas da parte dos súditos, não seria possível a doutrina do Estado liberal, que é in primis a doutrina dos limites jurídicos do poder estatal. Sem individualismo não há liberalismo."(grifos em itálico do autor; em negrito, meus). BOBBIO, Norberto. Liberalismo e Democracia. 6 ed. São Paulo: Ed. Brasiliense, 1994, p. 14/15. Salientando que o liberalismo e o organicismo repousam a primazia axiológica no indivíduo e na comunidade política, respectivamente, v. SARMENTO, Daniel. Interesses Públicos vs. Interesses Privados na Perspectiva da Teoria e da Filosofia Constitucional. In: SARMENTO, Daniel (org.). Interesses Públicos vs. Interesses Privados: Desconstruindo o Princípio de Supremacia do Interesse Público. Rio de Janeiro: Lumen Iuris, 2005, p. 51/59. No mesmo sentido ROUANET, Sergio Paulo. Mal-Estar na Modernidade. São Paulo: Companhia das Letras, 2001, p. 36, que arremata: "No entanto, sua consciência da dimensão social não impede que o iluminismo seja absolutamente alheio a qualquer concepção holista, a qualquer visão "orgânica" que atribua prioridade a uma instância coletiva - grupo, cultura, Estado - ou que diga que a verdade da parte está em sua inserção no todo". 12 LOCKE, John. Dois Tratados sobre o Governo. São Paulo: Martins Fontes, 2001. (a 1ª edição desta obra é de 1690).
} 
3 "Constitucionalismo sem democracia". Raízes teóricas e históricas do constitucionalismo: a tradição de limitação do poder político na obra de John Locke e na experiência políticoinstitucional inglesa.

Locke refuta concepções políticas pré-modernas que, fundadas em premissas teológicas (Bodin) ou patriarcais (Filmer), consideravam haver uma natural sujeição dos indivíduos ao poder absoluto dos monarcas (natural subjection doctrines), e, via de conseqüência, um dever incondicional de os primeiros obedecerem às determinações dos últimos.

A propósito, Locke dedica o Primeiro Tratado a uma frontal oposição ao livro "Patriarca", 11 onde Robert Filmer formulara uma tese muito conveniente às pretensões absolutistas da monarquia inglesa do século XVII, assim sintetizada: há uma sujeição natural e ilimitada dos indivíduos ao poder do monarca, de maneira que nenhuma forma de resistência justificar-se-ia. Filmer fundamenta tal assertiva numa teoria paternalista da soberania, através da qual busca assemelhar os poderes político e paterno, na medida em que equipara o poder exercido pelo monarca sobre os seus súditos ao poder ilimitado e arbitrário que os patriarcas exerciam sobre suas esposas, filhos, escravos e propriedades privadas; ambas as prerrogativas seriam, ao seu ver, absolutamente "naturais". ${ }^{12}$

Locke, contudo, partilha da visão de autores como Grotius e Hobbes, no sentido de que os indivíduos ostentariam uma liberdade natural (natural freedom doctrines), de modo que a sujeição política - é dizer, dos indivíduos às deliberações das autoridades - somente se perfectibilizaria por alguma forma de consentimento. Todavia, Locke não se limita à tradição contratualista, porquanto diverge dos seus próceres ao negar que a transposição do Estado de Natureza ao Estado Social implique uma alienação total ou quase total desta liberdade natural (alienation theories). ${ }^{13}$ Neste particular, é bastante conhecida a formulação pessimista de

\footnotetext{
${ }^{11}$ Escrito entre 1628 e 1653, e publicado em 1680. V. TULLY, James. An approach to political philosophy: Locke in contexts - Ideas in context. Cambridge: Cambridge University Press, 1993, p. 16.

${ }^{12}$ TULLY, James. Op. cit., p. 16.

${ }^{13}$ Afigura-se oportuno destacar que, embora Locke, em sua obra intitulada "Two Tracts on government" (não publicado) tenha esposado uma teoria da alienação à moda de Hobbes, essa posição foi abandonada em "Essay concerning toleration" (1667), tendo consolidado a sua nova concepção com os "Dois tratados sobre o governo
} 
Hobbes, segundo a qual a única alternativa ao anárquico e opressor Estado de Natureza seria a renúncia quase total dos direitos naturais - preservando-se, apenas, o direito à vida - em favor do estado civil, de maneira que não subsistiriam, ao seu ver, quaisquer mecanismos (nem mesmo o próprio direito natural) de aferição da justiça do direito posto. Considera, portanto, o soberano acima do direito (legibus solutos), circunstância que, ainda que por caminho diverso do percorrido por Filmer, impunha ao povo um dever de obediência incondicional às suas deliberações.

Em que pese a compartilhar com Hobbes a premissa da liberdade natural do indivíduo, o caráter e a extensão atribuídos por Locke ao consentimento dado pelos indivíduos no momento da transposição do Estado de Natureza para o Estado Civil revelam profundas fissuras entre o seu jusnaturalismo e o de Hobbes. ${ }^{14}$ Superado o clima turbulento presente na Inglaterra nos idos de 1640, em cujo período a luta incessante entre as forças sociais pela aquisição do poder soberano redundou em clima belicoso e na destruição das bases da Constituição mista, ${ }^{15}$ justificando, de certa forma, a ênfase hobbesiana na concentração do poder político no Estado tendo por fim a preservação das liberdades e da ordem pública através do direito positivo, o problema agora era outro: o menoscabo da liberdade individual e, em particular, da liberdade religiosa, pela atuação arbitrária da monarquia inglesa. ${ }^{16}$ Por outro lado,

civil" (1690). V. TULLY, James. An approach to political philosophy: Locke in contexts - Ideas in context. Cambridge: Cambridge University Press, 1993, p. 18 e 30-32.

${ }^{14}$ É bem de ver que, a busca desmedida por segurança e ordem, a utilização do jusnaturalismo em desconformidade à sua histórica função de limitação do poder, e a conseqüente redução do Direito ao direito positivo, torna Hobbes um jusnaturalista ao partir, e um positivista ao chegar. BOBBIO, Norberto. Op. cit., p. 41. Nada obstante, é bem de ver que as críticas à circunstância de a sua tese dar fundamento teórico ao absolutismo não-raro esmaecem a preocupação hobbesiana com o tema da liberdade, cujo relevo é comprovado, como visto alhures, pela circunstância de a sua teoria pressupor a liberdade natural dos indivíduos. Conflui com tal perspectiva, aliás, a divisão tripartite do De Cive: libertas, potestas e religio. Ocorre que, temendo o recrudescimento da desordem social instalada na Inglaterra de 1640, fomentada, notadamente, por motivos religiosos, Hobbes vislumbrava a proteção da liberdade por intermédio do direito posto pelo soberano. É o que nos esclarece, com a habitual acuidade, Merquior, arrematando que :"para proteger libertas, potestas devia controlar a farisaica religio". MERQUIOR, José Guilherme. O liberalismo antigo e moderno. 2 ed. São Paulo: Ed. Nova Fronteira. V. Hobbes, Thomas. Leviatan - o la materia, forma y poder de uma republica, eclesiastica y civil. Mexico: Fondo de Cultura Económica, 1992.

${ }^{15}$ Cf. FIORAVANTI, Maurizio. Constitución. De la Antiguedad a nuestros días, p. 68 e ss.

${ }^{16}$ O objetivo de Locke, confessado no prefácio dos Dois Tratados, era prover uma justificação racional e consistente à monarquia limitada instituída após o fim da Revolução Gloriosa (1689), com a assunção de Guilherme D'Orange ao trono inglês. Há, a propósito, uma infindável discussão a respeito desta monumental obra haver sido escrita após a eclosão do referido movimento revolucionário, com o escopo de justificá-lo, ou, ao revés, durante a década de 1680. Em que pese haver no prefacio confissão de que o livro destinava-se a "consolidar o trono de nosso grande restaurador, o Rei Guilherme (...)”, Laslett, na esteira da corrente majoritária, sustenta que Locke já vinha se 
afastadas as pretensões absolutistas da monarquia pela Revolução Gloriosa, as teorias de alienação total das liberdades naturais em favor do monarca (alienation theories), pareciam crescentemente implausíveis e indesejáveis a um povo que julgara e executara seu rei, e instituíra uma nova forma de governo, caracterizada, fundamentalmente, pela limitação do poder do Estado com o escopo de proteger os direitos individuais. ${ }^{17}$

Atendendo aos anseios dos seus concidadãos, Locke considera que, na passagem do Estado de Natureza para o Estado Social, os indivíduos preservariam os seus direitos naturais ligados à propriedade, ${ }^{20}$ à liberdade e à vida, renunciando, apenas, o direito de fazer justiça com as próprias mãos. ${ }^{18}$ Assim, a constituição do Estado Social dar-se-ia com o fito de garantir que um juiz imparcial zele pela aplicação coercitiva das leis naturais.

Os órgãos do Estado, e notadamente o principal deles, o Poder Legislativo, são vistos por Locke como "Fiduciary Power(s) to act to certain ends", de maneira que, se os órgãos estatais se voltarem contra os direitos naturais cuja proteção justificou a sua criação, perpetra violação à confiança que os indivíduos lhe depositaram. ${ }^{19} \mathrm{Na}$ alvitrada hipótese, Locke, mediante o emprego do eufemismo do "apelo aos céus" (appeal to Heaven), defende o direito de resistência, pois, se a constituição da sociedade civil se implementou em virtude da necessidade de dar-se maior segurança à fruição das liberdades inatas do indivíduo, com o “esclarecimento" do seu conteúdo e a garantia de que juízes irão aplicá-las imparcialmente, na hipótese de qualquer dos departamentos estatais as violarem o poder é devolvido ao povo, que, através do apelo aos céus, reagirá de forma justa ao injusto e abusivo exercício do poder civil (force without right). Portanto, o governo civil tem a sua legitimidade condicionada à efetiva observância dos direitos naturais, não apenas no estabelecimento do direito positivo, mas também na sua aplicação.

Para fins didáticos, revela-se interessante distinguir os efeitos que uma tal perspectiva individualista produziu sobre os conceitos de liberdades civis e políticas, ou seja, sobre as

dedicando ao escrito há muito mais tempo. V. LASLETT, Peter. Introdução aos dois tratados sobre o governo civil. São Paulo: Ed. Martins Fontes, Trad.: Julio Fischer, 2001, p. 66 et seq..

${ }^{17}$ TULLY, James. An approach to political philosophy: Locke in contexts - Ideas in context. Op. cit., p. $22 .{ }^{20}$ Locke não-raro engloba em seu conceito de propriedade, os direitos à vida e à liberdade. V. Locke, John, Dois Tratados sobre o Governo. op. cit., p. 495.

${ }^{18}$ LOCKE, John. Dois Tratados sobre o Governo, p. 498 e 499.

${ }^{19}$ As noções de consentimento e confiança - trust, embora de destacado relevo na arquitetônica lockeana, só serão lateralmente abordadas, tendo em vista os limites do vertente estudo. 
idéias de limitação do poder para a proteção do indivíduo e de autogoverno do povo. Quanto às liberdades civis, a afirmação da existência de uma sociedade civil de indivíduos titulares de liberdades civis e de propriedades, que seria prévia à formação do Estado, revela o papel limitado conferido ao direito positivo, qual seja o de garantir direitos que emigram do Estado de Natureza para o Estado Social, conferindo à tutela dessas situações jurídicas subjetivas a segurança e a certeza que a ordem jurídica é capaz de prover. Não há que se falar, portanto, em criação de direitos, mas tão-somente no seu reconhecimento, pois não se pode conferir a quem quer que seja o poder de dar azo a algo que já existe.

Reputando-se os direitos naturais anteriores e superiores ao ordenamento jurídicopositivo, eles assumiriam (i) natureza pré-política, porquanto imunes ao poder de deliberação dos poderes políticos (inclusive e notadamente do Parlamento), (ii) a nota de inalienabilidade, imprescritibilidade e universalidade, e (iii) serviriam de critério de legitimação do direito positivo, pois as normas e as práticas que com eles se afigurassem incompatíveis reputar-seiam inválidas.

Note-se que a concepção de Locke se inscreve em uma concepção jusnaturalista moderna, na medida em que o filósofo de Oxford, por um lado, deixou de conceber o Estado e o Direito como obra de Deus ou da tradição, mas como produto de seres racionais, ${ }^{2021} \mathrm{e}$, por outro lado, não mais considerava o direito natural como direito objetivo ou um conjunto de deveres do soberano, passando a vê-lo como uma ordem prenhe de direitos individuais oponíveis ao Estado, ${ }^{24}$ ordem esta inerente à natureza humana, descoberta pela razão e cuja implementação consistiria no objetivo último da constituição do Estado. Para além disto, podese inferir de sua obra premissas fundamentais à formulação das proposições básicas da concepção contemporânea do jusnaturalismo, senão vejamos: a primeira tese, de filosofia ética (T.1), preconiza a existência de princípios morais e de justiça que são universalmente válidos e acessíveis à razão humana; e a segunda, concernente ao conceito do direito (T.2), dispõe que

\footnotetext{
${ }^{20}$ SANCHÍS, Luis Prieto. Justicia constitucional y derechos fundamentales. Madrid: Editorial Trotta, 2003, p. 21 . BOBBIO, Norberto. Locke e o direito natural. Brasília: Ed. UnB, 1998 p. 29.
} 
uma norma não pode ser qualificada como jurídica se contrastar com tais princípios morais ou de justiça. ${ }^{22}$

Por outro lado, a obra de Locke também projeta intensas e novas luzes sobre o conceito de liberdade política. Isto porque nela se encontra a defesa da preexistência (relativamente ao Estado) não apenas de uma sociedade civil de indivíduos dotados de direitos naturais, como também de uma sociedade de indivíduos politicamente ativos. Neste particular, parece que a posição do filósofo inglês pode ser melhor compreendida se extremadas das perspectivas adotadas por Hobbes e Rousseau.

Saliente-se, a propósito, que os principais teóricos do absolutismo e da democracia confluem na utilização do pacto de associação (contrato que dá origem ao Estado Social), de um modo radicalmente contrário a Locke, nele vislumbrando uma alienação total dos direitos naturais, pela incondicional submissão dos indivíduos associados a um soberano que não é parte do contrato (Hobbes), ou que vocaliza a vontade geral da coletividade (Rousseau). ${ }^{23}$

Se o soberano assume o status de legibus solutus, não há que se cogitar da sua limitação por uma lei fundamental, porquanto a soberania veicularia uma vontade essencialmente livre, ilimitada e incessantemente chamada a redefinir a forma de governo e as instituições políticas, traduzindo-se em um exercício permanente do poder constituinte. A conclusão inevitável é que, em um tal modelo, há uma única lei fundamental, a saber: a obediência incondicional às deliberações do monarca ou da Assembléia soberana, os quais dispõem de uma vontade originária de criar uma Constituição.Tal norma só terá o condão de limitar os poderes que instituiu, e não o poder soberano que, precisamente por precedê-la e criá-la, pode alterar qualquer das disposições constitucionais. Em poucas palavras: o conceito de Constituição enquanto lei superior (higher law) desvincula-se do escopo de equilibrar e limitar o poder para a proteção do indivíduo (o que seria contrário ao caráter uno e indivisível do poder soberano),

\footnotetext{
${ }^{22}$ Utiliza-se aqui a profícua síntese de Carlos Santiago Nino a respeito das proposições básicas do jusnaturalismo. NINO, Carlos Santiago. Introdución al análisis del derecho. 11 ed. Barcelona: Ariel Derecho, 2003, p. 28. Convém destacar-se, contudo, que não há na obra de Locke a atribuição ao Judiciário do papel de guardião dos direitos fundamentais contra eventuais violações dos órgãos do Estado. Sobre o modelo lockeano de separação de poderes, ver infra (parte final do presente capítulo).

${ }^{23}$ Cf Contratualismo. In: MATEUCCI, Nicola. Dicionário de Política, p. 279. A propósito, Luis Prieto Sanchis assinala que: "pode parecer surpreendente, mas os dois grandes teóricos do absolutismo e da democracia, Hobbes e Rousseau, estão de acordo em dois aspectos essenciais: devemos obedecer as leis como se fossem expressões da nossa própria vontade, e que o poder absoluto não tem limites.” PRIETO SANCHÍS, Luis. Justicia Constitucional y derechos fundamentales, p. 70. A questão será aprofundada no subseqüente item.
} 
confundindo-se com a noção de soberania, ${ }^{24}$ assim entendida a vontade perpétua e absoluta de dispor sobre a forma de organização política de uma sociedade

concreta. $^{25}$

Já Locke, por sua vez, considera que, caso o governo se volte contra o propósito mesmo da sua instituição, é dizer, a tutela dos direitos naturais, distancia-se do seu suporte de legitimidade, autorizando que os indivíduos, por intermédio do exercício do direito de resistência, reassumam o poder político cuja originária titularidade lhes pertence. Tal formulação revela o verniz político conferido aos conceitos de liberdade natural e de direito de resistência, e, via de conseqüência, estabelece premissas fundamentais à construção de uma clara divisão entre poder constituinte e poderes constituídos, no sentido da impossibilidade de os últimos se imiscuírem em procedimentos e liberdades presentes em uma normatividade superior (seja o Direito Natural, seja a Constituição). ${ }^{29}-30$

Muito embora a precedência da sociedade de indivíduos politicamente ativos revele o início do desenvolvimento da noção da superioridade do poder constituinte do povo em relação aos poderes constituídos, não se pode identificar claramente na obra de Locke elementos fundamentais às modernas conceituações de poder constituinte do povo ou de soberania popular, especialmente a atribuição ao seu titular de um poder originário de criar novas formas políticas. ${ }^{31}$ De fato, a extensão conferida às liberdades políticas revela-se

significativamente menos ampla, já que o manejo do direito de resistência destina-se tãosomente a restaurar a ordem natural de direitos de liberdade e igualdade perturbada pelos poderes constituídos, refugindo do seu escopo a definição do conteúdo dos direitos individuais

\footnotetext{
${ }^{24}$ FIORAVANTI, Maurizio. Constitución. De La Antiguedad a Nuestros Días, p. 84/85.

${ }^{25}$ Vale salientar, contudo, que a colocação da noção de soberania no coração da Constituição dos modernos não deve levar à equivocada conclusão de que Hobbes e Rousseau coonestassem com o exercício arbitrário do poder político. Ao revés, a soberania era compreendida como um poder conferido pelos indivíduos ao monarca, à Assembléia soberana (Hobbes) ou ao povo (Rousseau), através do contrato social, o qual se afigurava essencialmente justo (Rousseau) e levara ao corrompimento da sociedade em anarquia e desordem, com inegáveis prejuízos à tutela dos direitos civis (Hobbes). Apesar deste escopo e da circunstância de ambas as concepções partirem da premissa da liberdade natural revelarem a adoção de perspectivas individualistas, buscar-se-á expor no subseqüente capítulo
} 
e o estabelecimento de uma nova forma de organização política, em ruptura com a que lhe precedeu. ${ }^{26}$

Em síntese, pode-se asseverar que o modelo político individualista, principal responsável pelo substrato filosófico das culturas (liberal e democrática) das liberdades individuais desde a sua gênese na Idade Moderna, assenta-se na concomitante afirmação das liberdades civis e políticas, ou seja, na concepção de que preexistem ao Estado, respectivamente, (i) um espaço de autonomia individual imune a ingerências estatais e (ii) um poder político originário de os indivíduos disporem sobre a atuação dos órgãos estatais. ${ }^{27}$

Tal constatação revela que as idéias de direitos individuais e de autogoverno do povo, apesar de recorrentemente expostas como colidentes, uniram-se na construção do modelo individualista que se opôs ao absolutismo monárquico ${ }^{28}$ Contudo, a ênfase conferida por um regime político concreto aos vetores da limitação do poder político mediante a supremacia dos direitos individuais em face de atos políticos ordinários ou, inversamente, ao poder de autogoverno do povo e de seus representantes em condições ordinárias de deliberação, revelará, respectivamente, uma maior aproximação do constitucionalismo ou da democracia.

A concepção lockeana, por sua vez, traduz perspectiva tipicamente liberal, "mais próxima", portanto, do constitucionalismo do que da democracia, porquanto confere à liberdade positiva a finalidade específica de restaurar os direitos naturais violados pelas instituições do Estado, não cabendo ao processo político-deliberativo decidir acerca do seu conteúdo (conforme defendido pelos “democratas"). O fruto do exercício da liberdade positiva - leia-se a Constituição e as leis - apresentava, portanto, um conteúdo necessário, qual seja a declaração e a conservação de direitos naturais supra positivos, circunstância que revela o

\footnotetext{
${ }^{26}$ Por outro lado, a concepção, por assim dizer, mais refinada, no sentido de que o poder constituinte do povo manifestar-se-ia através de um diploma jurídico escrito e superior às demais fontes do direito, bem assim de que caberia ao Poder Judiciário, através do mecanismo do controle da constitucionalidade das leis, zelar pela precedência da vontade do povo sobre a dos poderes constituídos, somente se aperfeiçoará com a experiência norteamericana.

${ }^{27}$ Ver, por todos, FIORAVANTI, Maurizio. Los Derechos Fundamentales - Apuntes de la Historia de las Constituciones.. 4 ed.Madrid: Editorial Trotta, 2003, p. 35 a 46.

${ }^{28}$ Veja-se, a propósito, os arts. 2 e 3 da Declaração Universal dos Direitos do Homem e do Cidadão de 1789: "Art. 2 - O fim de toda a associação política é a conservação dos direitos naturais e imprescritíveis do homem. Art. 3 - O princípio de toda a soberania reside na nação. Nenhuma corporação ou indivíduo pode exercer uma autoridade que não emane expressamente dela".
} 
caráter acessório conferido à liberdade positiva, e, inversamente, a primazia da liberdade negativa, erigida, repise-se, ao status de direito intangível ao processo políticodeliberativo.

Cumpre notar que a preocupação de Locke em limitar os poderes constituídos (inclusive o Legislativo) não se restringe à adoção de uma teoria política de caráter individualista, mas atinge também o domínio prático do desenho das instituições do Estado. Efetivamente, o filósofo inglês teme não apenas o absolutismo monárquico, mas igualmente a concessão de um poder ilimitado ao Parlamento, visto que, partindo de um pessimismo antropológico, de matiz tipicamente liberal, considera "uma tentação demasiado grande para a fragilidade humana confiar-se aos que já têm o poder de fazer as leis o poder de executálas". ${ }^{29}$ Assim, a elaboração periódica das leis e a sua permanente execução devem ser conferidas a órgãos estatais distintos, ${ }^{30}$ pois a concentração de tais poderes em um só órgão redundaria no estabelecimento de um soberano absoluto, incompatível com uma sociedade civil bem ordenada, já que inexistirá juiz com capacidade para julgar imparcialmente controvérsias, inclusive e notadamente aquelas que envolvam reparação de injúria causada pelo soberano. ${ }^{37}$

A vinculação da separação das funções estatais à necessidade de submissão de governantes e governados à lei evidencia que Locke esposa a doutrina da separação orgânicofuncional dos poderes como pré-requisito da rule of law (Estado de Direito), na medida em que a atribuição das funções legislativa e executiva a órgãos estatais distintos (separação orgânico-funcional) justifica-se ante a impossibilidade de os governantes sujeitarem-se a lei que eles próprios fazem e aplicam (Estado de Direito). Saliente-se ainda que, da postulação de que o governo se paute por "leis promulgadas e estabelecidas", é dizer, atos genéricos e abstratos, frontalmente opostos aos decretos casuísticos utilizados pelo monarca, decorre a supremacia da função legislativa, já que esta contém os critérios que serão necessariamente empregados pela função executiva para a solução de casos concretos, a qual se restringiria a uma atividade de aplicação da lei preexistente. ${ }^{31}$

\footnotetext{
${ }^{29}$ LOCKE, John. Dois Tratados sobre o Governo. Cap. XII, parágrafo 143, p. 514/515.

${ }^{30}$ Ibid. Cap. XII, parágrafos 143 e 144 , p. $515 .{ }^{37}$

Ibid. Cap. VII, parágrafo 91, p. 462 e 463.

${ }^{31}$ PIÇARRA, Nuno. A Separação dos Poderes como Doutrina e Princípio Constitucional - Um Contributo para o Estudo das suas Origens e Evolução. Coimbra: Coimbra Editora, 1989, p. 74 e ss.
} 
Como corolário do exposto, o modelo lockeano de separação de poderes afirma a supremacia do Parlamento, em virtude de considerar este departamento estatal a "expressão primacial da vontade popular" ${ }^{32}$, relegando a contenção do arbítrio legislativo a limites intraorgânicos (participação do monarca hereditário, da nobreza e de representantes do povo no âmbito do Parlamento, segundo a fórmula britânica do governo misto) e extra-estaduais (precisamente o direito de resistência dos indivíduos para a tutela das liberdades civis), mas não interorgânicos. Assim, não confere, por exemplo, ao Poder Judiciário, o poder de controlar constitucionalidade das leis, inclusive porque lhe negava o status de poder autônomo. ${ }^{33}$ Acima do Legislativo, vislumbrava apenas o poder supremo do povo, cuja atuação direta somente ocorreria em momentos-limite, de ruptura, em que o Parlamento houvesse abusado do encargo que lhe fora confiado pelos cidadãos (apelo aos céus).

É lícito concluir que Locke, não obstante considerar a origem e o fundamento do poder político um fato convencional, e, de conseguinte, não natural - circunstância que, como salientado alhures, afastava-o definitivamente do modelo das Constituições mistas medievais , não abandonou a tradição de contenção do poder político mediante o seu compartilhamento entre órgãos distintos, como fizeram os teóricos da soberania. Neste viés, Locke mostrou-se pioneiro em articular a artificialidade da criação do Estado através do contrato social com uma perspectiva de moderação no exercício do poder político, que assegurava à Constituição o seu tradicional papel de espaço de equilíbrio dos poderes públicos com o fito de evitar a formação de poder absoluto que pusesse em risco os direitos do indivíduo, de modo que estabeleceu bases filosóficas imprescindíveis para a construção do constitucionalismo moderno.

Embora no domínio teórico somente vá se encontrar a noção de separação dos poderes vinculada ao equilíbrio e às mútuas interpenetrações entre os departamentos do Estado nos escritos, respectivamente, de Montesquieu e Madison (balança entre os poderes ou checks`n`balances), o embrião do mecanismo da balança de poderes já podia ser extraído da experiência constitucional britânica do século XVII.

Há, nesse particular, duas variantes cronologicamente situadas. A primeira, como salientado acima, é a do governo misto (governo misto ou King in Parliament, que se

\footnotetext{
${ }^{32}$ Ibid., p. 76

${ }^{33}$ V. LOCKE, John. Op.cit., Cap. IX - dos fins da sociedade política e do governo.
} 
desenvolveu no âmbito da "Constituição dos antigos" ${ }^{34}$ ), a qual se destinava a promover equilíbrio e controle recíprocos entre as forças sociais relevantes à época, no âmbito interno do Parlamento. Como essa variante busca equilíbrio (i) no interior do Legislativo, estabelece mecanismos de controle de caráter intra-orgânico, e por (ii) referir-se, precipuamente, à harmonização do poder de influência de forças sociais e não de órgãos estatais, avulta a sua dimensão político-social em detrimento da político-institucional.

Em que pese à busca de equilíbrio entre monarca, aristocratas e comuns repercutir, reflexamente, no âmbito institucional das relações entre Executivo e Legislativo, sobretudo ao promover a distinção entre as prerrogativas régias exercidas isoladamente e as que pressupõem autorização parlamentar, ${ }^{42}$ a pretensão de equilibrarem-se, especificamente, os "poderes" do Estado (Executivo, Legislativo e Judiciário), através de mecanismos de controle mútuo (balança entre os poderes), somente se perfectibilizará quando se firmar a idéia de que tais departamentos estatais gozam de funções típicas (executiva, legislativa e judicial) que lhes são preferencialmente atribuídas (separação orgânico-funcional dos poderes). Todavia, até o século XVII, a tarefa de legislar não gozava de autonomia e de relevância política, estando indissociavelmente imbricada com a de julgar, porquanto se entendia que a lei era declarada, e não feita, com o objetivo de solucionar casos concretos. ${ }^{35}$

Com a afirmação da noção de que as leis constituíam os critérios genéricos e abstratos para a solução de casos concretos, obtém-se a autonomização e a supremacia da função legislativa em relação à executiva (que, à época, abrangia as funções administrativa e judicial), já que a função executiva se restringirá à aplicação de lei anterior para dirimir controvérsias. A doutrina original do rule of law (Estado de Direito), embora esteja a serviço da supremacia da função legislativa, desconfia da concessão ao Parlamento dos poderes de fazer e aplicar a lei, sob o argumento de que tal concentração de poderes, ao invés de debelar o exercício absoluto e arbitrário do poder, apenas constituiria novo tirano (o Parlamento em substituição ao monarca). ${ }^{36}$

\footnotetext{
${ }^{34}$ Ver seção 2.

${ }^{42}$ Ver seção 2.

${ }^{35}$ Além disto, o Rei, através dos seus poderes de prerrogativa, era o centro da atividade do Estado, embora estivesse cada vez mais jungido à aquiescência do Parlamento em determinadas matérias, tais como a instituição de impostos e a alienação de bens públicos. V. PIÇARRA, Nuno. Op. cit.

${ }^{36}$ Ibid., p. 82.
} 
Linhas acima vimos que Locke chegara até esse ponto, ou seja, esposara um modelo de equilíbrio entre as forças sociais no seio do Parlamento (governo misto) e de separação das funções estatais como pré-requisito para o governo das leis e não dos homens (separação orgânico-funcional como condição ao Estado de Direito, ou simplesmente, rule of law). Todavia, fenômeno interessante se verificou na Inglaterra a partir da segunda metade do século XVII, com a simbiose entre governo misto e separação orgânico-funcional como pressuposto ao Estado de Direito, da qual nasce a separação dos poderes como conjunto de mecanismos interorgânicos de controle mútuo (balança de poderes), segundo a clássica formulação de Montesquieu.

Com efeito, a balança de poderes ou checks and balances consiste em mecanismo que comunga da perspectiva de que a atribuição das funções estatais a órgãos distintos é fundamental ao Estado de Direito, assertiva que a aproximava da rule of law (tal noção não foi elaborada pela doutrina do governo misto). Todavia, além de separar, de conceder atribuições próprias aos poderes do Estado, necessário se afigurava também equilibrá-los, conforme preconizado pelo governo misto e olvidado pelo rule of law. Contudo, na doutrina da balança entre os poderes tal equilíbrio dar-se-á, especialmente, através de mecanismos de controle mútuo entre os órgãos do Estado, ${ }^{37}$ e não através da harmonização das (i) forças sociais (ii) no interior do Parlamento (governo misto). Assim, enquanto no governo misto vislumbra-se (i) a preponderância de uma dimensão político-social e a (ii) busca de moderação governamental através de mecanismos intra-orgânicos (internos ao Parlamento), na balança de poderes constata-se a utilização de mecanismos interorgânicos ("controle externo dos poderes"), além de a ênfase ser conferida à dimensão político-institucional (objetivo imediato é o equilíbrio entre órgãos estatais independentes, notadamente Legislativo e Executivo, e não entre forças sociais, como o rei, a aristocracia e a burguesia). ${ }^{38}$

\footnotetext{
${ }^{37}$ Confira-se passagem clássica de Montesquieu, verbis: “eis, portanto, a constituição fundamental do governo de que falamos: sendo o corpo legislativo composto por duas partes, uma encadeará a outra pela mútua capacidade de impedir. Ambas estarão ligadas pelo Executivo que, por sua vez, o estará pelo poder legislativo. Esses três poderes deveriam formar um repouso ou uma inação. Mas, como pelo movimento necessário das coisas, são constrangidos a atuar, serão forçados a atuar em concerto". MONTESQUIEU. Charles de Secondat. The Spirit of Laws. William Benton Publisher: London, 1952.

${ }^{38}$ PIÇARRA, Nuno. Op. cit. p. 82. Cumpre notar que com a restauração da monarquia em 1660, por mais que o Legislativo e o Executivo viessem a, progressivamente, afirmar-se como instituições políticas independentes, havia ainda um indissociável vínculo entre as prerrogativas do Rei e a legitimidade monárquica, e as atribuições do Parlamento e a legitimidade democrática. Essa querela de legitimidades impedirá o pleno desenvolvimento da
} 
A influência que os métodos da Constituição mista, do governo misto, da separação orgânico-funcional e da balança dos poderes exerceram na Inglaterra, no que toca ao equilíbrio e ao fracionamento dos poderes estatais, ajuda a compreender a circunstância de este país ter evoluído "de um Estado estamental a um Estado constitucional-representativo, sem praticamente a ter feito conhecer um Estado absolutista", ${ }^{47}$ possuindo o arranjo político que, até o surgimento dos EUA, consistia no modelo de constitucionalismo por excelência. A propósito, os ingleses desconfiavam da atribuição de poderes absolutos a quem quer seja, porquanto tal concepção, ao submeter a definição de liberdades consolidadas pela história aos atropelos unilaterais daqueles "corpos constituintes", criaria forte dose de instabilidade política e evidentes prejuízos à sua tutela, parecendo infactível e algo totalizante que os diferentes grupos de interesse existentes na sociedade logrem unir-se em uma só vontade constituinte, comum e essencialmente reta.

Assim, na obra de Locke e na experiência político-institucional inglesa, as liberdades políticas, conforme concebidas por Locke, assumirão uma abrangência muito mais restrita do que a atinente, por exemplo, ao conceito francês de poder constituinte. De fato, a ausência de Assembléias Constituintes na Inglaterra denota que não haverá de falar-se, neste país, de momentos constituintes nos quais o povo decide soberanamente sobre a estruturação do Estado e as normas fundamentais regentes da vida em sociedade. Ao contrário, as liberdades políticas têm como precípua finalidade a garantia da conservação dos direitos historicamente adquiridos, guardando, portanto, uma natureza acessória em relação às liberdades civis.

À guisa de conclusão, pode-se afirmar que o edifício teórico de Locke e a experiência política-institucional inglesa, ao enfatizarem a tutela das liberdades civis em relação às políticas, através (i) dos citados mecanismos institucionais de harmonização entre as forças sociais e as instituições públicas, (ii) da noção de direitos historicamente fundados e imunes aos "poderes constituídos", da (iii) adoção de uma postura jusnaturalista carente de toda a carga contra o passado, mas destinada a conservar tais direitos, (iv) da independência dos juízes e da tradição do commom law, etc., produziu um modelo que enfatizava os mecanismos de

institucionalização acima referida, algo que só acontecerá com o movimento revolucionário norte-americano, que, como se sabe, floresceu em uma sociedade politicamente homogênea, livre, portanto, de amarras estamentais e de formas de legitimação do poder político diversas do princípio republicano (não havia nos EUA, p. ex., as figuras do monarca e dos aristocratas). ${ }^{47}$ PIÇARRA, Nuno. Op. Cit., p. 42. 
limitação do poder e de proteção do indivíduo em detrimento do poder de autodeterminação coletiva do povo, aproximando-se mais do ideal constitucionalista do que do democrata. ${ }^{39}$

4 "Democracia sem constitucionalismo": os riscos da incorporação da Constituição pela soberania, analisados a partir da perspectiva do Estado de Direito legalista do século XIX

$\mathrm{Na}$ França pós-revolucionária constata-se, em cotejo com a experiência inglesa, um equilíbrio distinto no que concerne à relação entre as liberdades civis (direitos individuais) e as liberdades políticas (soberania do povo ou da nação), especialmente em virtude de substanciais distinções no tocante à disposição das instituições políticas, à teoria política prevalecente e ao contexto histórico. Neste diapasão, cumpre salientar que a célebre Declaração Universal dos Direitos do Homem e do Cidadão de 1789 alicerça-se, paralelamente, na consagração (i) dos direitos individuais como valores-guia da ação governamental e (ii) da soberania da nação como fonte de todo o poder político. ${ }^{40}$ Qual seria, então, o liame existente entre soberania da nação ou do povo e tutela dos direitos individuais em França? A análise desse modelo parece especialmente elucidativa, tendo em vista o mesmo haver fornecido elementos fundamentais à construção do modelo de Estado de Direito legalista prevalecente na Europa Continental do período pós-revolucionário até a Segunda Guerra Mundial.

A França, em oposição à Inglaterra, ao olhar para trás não vislumbrava uma edificante e vitoriosa luta pela aquisição de direitos contra o Estado, mas uma ordem de privilégios estamentais e de dominação do povo por atos casuísticos e arbitrários do monarca e dos

\footnotetext{
${ }^{39}$ FIORAVANTI, Maurizio. Constitución. De La Antiguedad a Nuestros Días, p. 109.

${ }^{40}$ Esta Declaração, que consistia em preâmbulo à Constituição de 1791, continha os princípios de filosofia política que inspiravam o espírito revolucionário. V. BURDEAU, Georges. Droit Constitutionnel et Institutions Politiques. Paris: Librairie Générale de Droit et de Jurisprudence, 1980, p. 297.

Confira-se, a propósito, os seus artigos 2 e 3, verbis: “A finalidade de toda associação política é a conservação do direitos naturais e imprescritíveis do homem ... (art. 2), cujo desrespeito é a única causa da desgraça dos governos (acrescenta o preâmbulo); O princípio de toda a soberania reside essencialmente na nação. Nenhuma corporação, nenhum indivíduo pode exercer autoridade que dela não emane expressamente (art. 3)".

A tensão entre as perspectivas liberal - preestatalidade e superioridade dos direitos individuais - e democrática caráter ilimitado da soberania do povo ou da nação - se intensifica ao percorrerem-se os demais dispositivos da Declaração. Por um lado, verifica-se um reconhecimento formal da preexistência de diversos direitos individuais, cumprindo citar, além do preâmbulo, a positivação de diversas liberdades civis, v.g..: nos arts. 7 a 9 típicas garantias processuais, nos arts. 10 e 11 as liberdades religiosas e de manifestação do pensamento, no art. 17 a inviolabilidade e a sacralidade do direito de propriedade, enquanto o Art. 16 estabelece um conteúdo material necessário de todas as Constituições não despóticas, já que aquelas que não dispuserem da garantia dos direitos e da separação de poderes não seriam, propriamente, Constituições.
} 
senhores feudais contra a qual violentamente se insurgira no período revolucionário. De fato, constata-se na experiência francesa forte necessidade de ruptura com os particularismos e privilégios do ancièn regime, verdadeira "fratura de época", ${ }^{50}$ circunstância que inviabilizou que se seguisse a experiência britânica de uma lenta e gradual "reforma da monarquia em sentido constitucional", através do equilíbrio entre os elementos monárquico, aristocrático e democrático no seio do Parlamento. ${ }^{51}$ Ao revés, a preocupação dos franceses se referia à questão de saber quem deve legislar e com que programa político deve fazê-lo, mais do que definir limites ao exercício desse mister. Acabaram, assim, por conferir o status de soberano ao povo ou à nação em substituição ao monarca, alterando-se a titularidade e não propriamente a natureza perpétua e absoluta que desde Bodin se atribui à soberania ${ }^{52}$.

Rousseau, a propósito, salienta que as deliberações públicas obrigam os súditos, mas não o povo, pois não se afigura possível o soberano obrigar-se em face de si mesmo, sendo “contra a natureza do corpo político impor-se o soberano uma lei que não possa infringir". ${ }^{53}$ Estando, portanto, o corpo soberano do povo acima do direito, assume a condição de legibus

solutus, similar à anteriormente atribuída ao monarca, não cabendo cogitar-se de "nenhuma espécie de lei fundamental obrigatória para o corpo do povo, nem mesmo o contrato social". ${ }^{41}$ Convém ressaltar que o caráter unitário e ilimitado conferido por Rousseau à vontade geral fez radicar a soberania no povo, ${ }^{55}$ assim entendido o corpo uno e homogêneo de cidadãos livres e iguais, em frontal oposição à fragmentação do poder político e à divisão estamental da sociedade típicos da Idade Média. Afigura-se, pois, lícito asseverar que o filósofo genebrino "forneceu o mais sólido instrumento político-ideológico de ruptura com o sistema jurídicofeudal". ${ }^{42}$

Por outro lado, tal perspectiva inspirou fortemente o alargamento da noção de liberdade política que se verificou com a obra clássica de Sieyés, no sentido de vislumbrá-la, não apenas como a prerrogativa de celebrar um contrato de garantia, que, no caso de malferimento dos

\footnotetext{
${ }^{41}$ ROUSSEAU, Jean Jacques. Op. cit., Livro I, Cap. VII, p. 23. Sieyès, embora se refira ao conceito abstrato de nação, esposa entendimento análogo, ao assinalar que a nação está sujeita unicamente ao (fluido) limite do direito natural, não havendo que se falar em contenções de ordem jurídico-positiva, pois (i) não se pode cercear o poder de o soberano promover as mudanças exigidas pelo interesse geral, (ii) nem se cogitar de celebração de contrato consigo mesmo. SIEYÈS, Emmanuel Joseph. Qu'est-ce que le Tiers État. Rio de Janeiro: Liber Juris, Rio de Janeiro, p. 118/119. 55 Em um primeiro momento, contudo, prevaleceu na França a tese de que a soberania caberia à Nação. Ver infra.

${ }_{42}$ PIÇARRA, Nuno. Op. cit., p. 139.
} 
direitos naturais, autorizaria o exercício do direito de resistência (como no modelo lockeano); mas associando-a à noção de poder constituinte, "entendido como poder originário e soberano de os cidadãos politicamente ativos decidirem sobre a sorte futura do modelo políticoconstitucional". Trata-se, portanto, de um poder originário, porque prévio ao Estado; soberano, visto incidir sobre um campo normativo praticamente ilimitado; e cujo conteúdo seria eminentemente político, na medida em que se trataria do poder de o povo ou nação eleger um novo modelo político-institucional que substituísse o antigo, estatuindo metas e diretrizes que vinculariam os órgãos do Estado. ${ }^{43}{ }^{44}$

A ênfase conferida pelo modelo francês às liberdades políticas revela-se não apenas no conceito de poder constituinte, mas também através de uma ideologia legalista. ${ }^{45}$ Com efeito, em França atribuiu-se à lei uma mais-valia em relação à perspectiva estritamente liberal, porquanto ela não mais é considerada um mero instrumento de conservação de direitos naturais preexistentes de forma autônoma, mas elemento necessário para a sua definição e tutela ${ }^{46}$, conforme dispõe textualmente o art. 4 da Declaração. A obra de Rousseau e, em especial, o seu conceito de vontade geral (volonté generalé), desempenharam papel de destaque na afirmação do legalismo.

\footnotetext{
${ }^{43}$ FIORAVANTI, Maurizio. Op. cit., p. 63/64.

${ }^{44}$ Sobre a incompatibilidade desta noção de poder constituinte com o modelo inglês, ver seção anterior.

${ }_{45}^{4}$ FIORAVANTI, Maurizio. Los Derechos Fundamentales - Apuntes de la Historia de las Constituciones, p. 62/75.

${ }^{46}$ Ibid., p. 62/63.

Por outro lado, nota-se a atribuição de um papel extremamente relevante à lei, porquanto os revolucionários franceses consideram-na "expressão da vontade geral" (art. 6), fonte de todas as obrigações (art. 5), única responsável pela definição de crimes e cominação de penas (arts. 7 e 8), etc.

Todavia, o caráter paradoxal da relação entre constitucionalismo e democracia parece melhor sintetizado no art. 4 , pois esse dispositivo, apesar de preconizar uma presunção geral de liberdade anterior ao Estado, a qual só poderia ser limitada por igual liberdade natural dos demais indivíduos (assertiva típica de um jusnaturalismo à moda de Locke), acaba por atribuir à lei a tarefa de determinar concretamente tais limites (aproximando-se de uma perspectiva democrática). 50

FIORAVANTI, Maurizio. Los Derechos Fundamentales - Apuntes de la Historia de las Constituciones. op. cit. 51 Id. Ibid. p. 59 a 62.

ROUSSEAU, Jean Jacques. O Contrato Social - Princípios de Direito Político. São Paulo: editora Martins Fontes, 2003, Livro I, Cap. VII, p. 23.

61

PARAMO ARGUELLES, Juan Ramon. Rousseau, estado de derecho, democracia y derechos. In: PECESBARBA MARTINES, Gregorio et al. Historia de los derechos fundamentales. Tomo II: Siglo XVIII, Volumen II - La filosofía de los derechos humanos.
} 
Rousseau, embora sustentasse que a liberdade é elemento distintivo dos seres humanos ${ }^{61}$ e que esse valor e o da igualdade dos homens devem ser "o fim de qualquer sistema de legislação", ${ }^{7}$ já desconfiava do caráter metafísico e incerto de leis naturais supra positivas, razão pela qual considera ser a lei (do Estado) o único instrumento capaz de outorgar validade jurídica a idéias moralmente valiosas, ${ }^{48}$ visto que o procedimento democrático conferiria às leis da natureza a aceitabilidade recíproca sem a qual seriam vãs princípios de justiça. ${ }^{49}$ Daí decorre que "todos os direitos são estabelecidos pela lei". 50

A propósito, o filósofo genebrino promove uma dessubstancialização das cláusulas do contrato social, porquanto as despoja de todo o conteúdo substantivo inerente aos direitos naturais que pudesse vir a condicionar a vontade dos associados, ${ }^{51}$ já que "(b)em compreendidas essas cláusulas se reduzem todas a uma só, a saber, a alienação total de cada associado, com todos os seus direitos, a toda a comunidade", ${ }^{52}$ cabendo à comunidade se expressar soberanamente através da lei, reveladora da vontade geral do povo. De tal assertiva não decorre que Rousseau haja assumido uma postura de relativismo ético, que marcara a face mais crua do positivismo jurídico (mormente em sua vertente ideológica), visto que, embora repute elitista a perspectiva jusnaturalista que vincula a validade de leis positivas a uma ordem de valores descoberta pela "razão ilustrada dos filósofos" ${ }^{53}$, não descura das condições de justiça do direito. Ao contrário, procedimentaliza tais condições, na medida em que posiciona o seu conceito de vontade geral no espaço antes ocupado pelos direitos naturais, como se infere da análise das duas vertentes básicas daquele conceito.

A primeira delas se refere à autoria e às condições de elaboração das leis. Com efeito, é assaz conhecida a formulação rousseauniana de que os cidadãos seriam efetivamente livres, caso pudessem deliberar, diretamente e em condições de igualdade, acerca do teor das leis que lhes são obrigatórias, de maneira a garantir uma identidade entre as figuras de autor e

\footnotetext{
${ }^{47}$ ROUSSEAU, Jean Jacques. O Contrato Social - Princípios de Direito Político, p. 62.

${ }^{48}$ PARAMO ARGÜELLES, Juan Ramon. Op. cit., p. 281.

${ }^{49}$ ROUSSEAU, Jean Jacques. Discurso sobre a origem e o fundamento da desigualdade entre os homens. In: ROUSSEAU, Jean Jacques. Textos Filosóficos. São Paulo: Paz e Terra, 2002; ROUSSEAU, Jean Jacques. O Contrato Social - Princípios de Direito Político., Livro I, Cap. VI, p. 46

${ }^{50}$ ROUSSEAU, Jean Jacques. O Contrato Social - Princípios de Direito Político., Livro I, Cap. VI, p. 46

${ }^{51}$ PRIETO SANCHÍS, Luis. Justicia Constitucional y derechos fundamentals, p. 66.

${ }^{52}$ ROUSSEAU, Jean Jacques. O Contrato Social - Princípios de Direito Político. Livro II, Cap. VI, p. 46.

${ }^{53}$ PARAMO ARGÜELLES, Juan Ramon. Op. cit., p. 288.
} 
destinatário do direito, cidadão e súdito, e, via de conseqüência, assegurar o conteúdo essencialmente justo das leis, pois "não é preciso perguntar (...) nem se a lei pode ser injusta, porquanto ninguém é injusto consigo mesmo, nem como se é livre e ao mesmo tempo submisso às leis, já que estas são meras expressões de nossa vontade". ${ }^{54}$ Deve, portanto, "todo o povo estatuir sobre todo o povo" ${ }^{, 55}$; esta seria a primeira condição de justiça da lei.

Para além da questão relativa à fonte, o conceito de vontade geral traz também exigências a respeito da estrutura das leis, a saber: devem elas, necessariamente, ter conteúdo genérico e abstrato, isto é, "considera(r) os súditos coletivamente e as ações como abstratas, nunca um homem como indivíduo nem uma ação como particular", 71 "perdendo a sua retidão natural quando tende(m) a algum objeto individual e determinado", ${ }^{56}$ como, i.e., os atos casuísticos do monarca que oneravam mais intensamente uns súditos do que outros, segundo o modelo de dominação pessoal característico do antigo regime.

A vontade geral, ainda que possa ser aferida mediante deliberação majoritária, não se reduz a um conceito estatístico, como a soma de interesses individuais ou a representação dos interesses da maioria, mas seria genuína expressão do bem comum, do acordo entre interesses individuais que tornou possível o estabelecimento das sociedades, ${ }^{57}$ e que restabelece a igualdade natural dos homens. ${ }^{58}$ De conseguinte, o governo republicano - assim entendido aquele em que o interesse público cristalizado na lei submete governantes e governados - seria

\footnotetext{
${ }^{54}$ ROUSSEAU, Jean Jacques. Op. cit., Livro II, Cap. VI, p. 47.

${ }^{55}$ Ibid. Ressalte-se que Rousseau, no Contrato Social, preconiza uma participação direta e ativa dos cidadãos no espaço público, considerando a soberania popular inalienável e, por conseguinte, insuscetível de representação. Assinala, por outro lado, que a condição de cidadão deveria se dar com abstração de distinções econômicas, relativas ao sexo ou à formação intelectual ou acadêmica dos indivíduos, adotando uma concepção abrangente de povo que se consubstancia em relevante antecedente teórico das lutas pelo sufrágio universal. Já Sieyès considera que os representantes da nação, reunidos em Assembléia Nacional Constituinte em virtude de comissão extraordinária recebida do titular da soberania, são "os únicos representantes da vontade geral, não têm necessidade de consultar os constituintes sobre dissenção que não existe", muito embora prevalecesse à época o voto censitário. Cf. ROUSSEAU, Jean Jacques. Op. cit., especialmente, Livro II, Cap. I, e Livro III, Cap. XIV. A respeito da abrangência do conceito de cidadão na obra de Rousseau, confira-se PARAMO ARGUELLES, Juan Ramon. "Rousseau, Estado de Derecho, Democracia y Derechos"; SIEYÈS, Emmanuel Joseph. Op. cit., p. 139. 71

ROUSSEAU, Jean Jacques. O Contrato Social - Princípios de Direito Político.

${ }^{56}$ Ibid., Livro II, Cap. IV, p. 40.

${ }^{57}$ Ibid, Livro II, Cap. I, p. 33

${ }^{58}$ Ibid., Livro III, Cap. X, p. 103. Parece evidente que, por trás dessa mitificação das manifestações em geral do povo soberano, se encontra a arraigada crença republicana na virtude cívica dos indivíduos, ou, em termos contemporâneos, no resultado inevitavelmente justo da (contrafática) participação livre, igual e ativa dos cidadãos no espaço público, que assumiria, assim, as características de um ambiente ideal de deliberação. Mitificação essa que parece ter sido reconhecida pelo próprio Rousseau, ao asseverar que: "haveria necessidade de deuses para dar leis aos homens". Ibid., Livro II, Cap. VII, p. 49. ${ }^{75}$ PRIETO SANCHÍS. Op. cit., p. 67 a 72.
} 
a única forma de governo legítimo. Rousseau, ao afirmar que "se aquele que manda nos homens não deve mandar nas leis, aquele que manda nas leis não deve mandar nos homens", deixa claro que ninguém pode se reputar acima da lei, pois apenas o povo soberano, que se expressa através de uma vontade geral transcendente dos interesses particulares de grupos ou facções, tem o status de legibus solutus. Assim, o filósofo genebrino "antecipa a separação entre governo e soberano, e sua conseqüência mais imediata, o governo das leis", promovendo clara racionalização do poder em oposição à teoria da origem divina do poder monárquico, tão em voga na França pré-revolucionária. Evidente se afigura a relevância da sua obra para a construção da noção de Estado de Direito.

À luz do exposto, pode-se concluir que o modelo francês apresentou, sobretudo quando comparado ao inglês, um alargamento da noção de liberdade política, porquanto conferiu ao povo ou à nação um poder originário, soberano e exclusivo de dispor sobre as instituições políticas e assuntos de interesse público (inclusive podendo proceder a significativas rupturas com a ordem política anterior e definir o conteúdo concreto dos direitos individuais). Todavia, a enfatização da exigência de legitimidade democrática do direito não correspondeu, quando menos em teoria, a um descuramento da sua justiça intrínseca. Ao revés, nessa espécie de legalismo ético, a lei assumia uma dupla e cumulativa função: (i) instrumento de soberania, de autogoverno do povo, (ii) e mecanismo fundamental à tutela das liberdades civis. ${ }^{75}$ Mas como se hão de equilibrar as exigências tendencialmente antagônicas de positividade e de justiça do direito? Mais especificamente, como sanar a contradição inerente à afirmação de que, não obstante remanesçam como fundamentos da associação política, as liberdades individuais podem ser inteiramente configuradas pelo legislador?

Enfim, quem garante que o Legislador não irá, a pretexto de definir o seu conteúdo, suprimir garantia inerente ao núcleo essencial de um direito individual? A resposta a essas complexas perguntas é tremendamente simples, como anota Fioravanti: “o legislador não pode lesionar os direitos individuais porque é necessariamente justo", 5960 exatamente por vocalizar a vontade

\footnotetext{
${ }^{59}$ FIORAVANTI, Maurizio. Los Derechos Fundamentales - Apuntes de la Historia de las Constituciones. p. 60
} 
geral que, em virtude dos requisitos antes analisados, "é invariavelmente reta e tende à utilidade pública". 61

Nada obstante, o transplante mal-sucedido do sonho comunitário de uma democracia participativa, acalentado por Rousseau, para o plano concreto das instituições e da práxis política de um país recém-liberto dos grilhões do absolutismo, revelou a fragilidade de conferirse a tutela dos direitos individuais tão-somente às "luzes de um Legislador virtuoso". Tal circunstância denota que a discussão específica acerca da identificação do conteúdo e dos instrumentos de tutela das liberdades civis na Revolução Francesa foi incorporada pelo debate afeto à soberania, às liberdades políticas. ${ }^{62} \mathrm{E}$, descendo da abstração das teorias políticas para as propostas de desenho institucional da nação, constatou-se no curso do período revolucionário um movimento pendular entre a defesa de concepções antagônicas: uma radicalmente democrática, de lastro individualista; outra conservadora, de matiz estatalista. ${ }^{63}$

De um lado, encontrava-se a defesa de uma democracia direta que, forte nas lições de Rousseau a respeito da noção de soberania popular e da inviabilidade do seu exercício mediante representação, salientava que a revolução se fundou na atribuição aos cidadãos de um poder soberano e originário de dispor sobre a estrutura do Estado e demais assuntos de interesse coletivo. Afirma-se, assim, uma concepção individualista acerca da origem do poder político, frontalmente contrária ao estatalismo prevalecente na tradição monárquica, porquanto se postula a prioridade do corpo de cidadãos constituintes, autonomamente existente e politicamente atuante, sobre as instituições políticas.

Ademais, preconizam os jacobinos uma cidadania ativa, a participação direta dos cidadãos na vida política através das assembléias primárias, ${ }^{64}$ de maneira que a adoção de um modelo representativo de democracia significaria "trair" o espírito revolucionário, visto redundar no restabelecimento da noção estatalista de que o povo ou nação não existiria

\footnotetext{
${ }^{61}$ ROUSSEAU, Jean Jacques. Op. cit., Livro II, Cap. III, p. 37. Evidentemente que subjaz a tal perspectiva a idéia de cooriginalidade entre democracia e liberdades individuais, ou seja, de que existiria uma correlação lógiconormativa entre tais valores, porquanto sem democracia não haveria propriamente direitos (meros princípios morais carentes de validade jurídica), e só um procedimento que reconheça direitos se pode dizer, efetivamente, democrático (afastando-se de concepções formais de democracia).

${ }^{62}$ FIORAVANTI, Maurizio. Op. cit., p. 75.

${ }^{63}$ FIORAVANTI, Maurizio. Op. Cit.

${ }^{64}$ Cite-se, por exemplo, entre os poderes reservados às Assembléias Primárias, as prerrogativas de referendar as leis aprovadas pelo Corpo Legislativo, de deflagrar o processo de alteração da Constituição de 1793 , etc. V. BURDEAU, Georges. Droit Constitutionnel et Institutions Politiques, p. 305 et. seq.
} 
autonomamente senão através da representação de uma autoridade constituída (Monarca ou Parlamento). Em uma só palavra: a democracia representativa implicaria apenas a substituição do soberano por outra entidade representativa: ${ }^{65}$ não mais o Rei, mas o Parlamento, ambos sem plena legitimidade democrática, já que esta repousaria apenas nas manifestações diretas do povo.

Por outro lado, à exaltação da democracia direta se opõe visão que superlativiza as virtudes da democracia representativa, ao atribuir ao Parlamento o papel de revelar, com exclusividade, a vontade geral que transcende as particularidades dos interesses de facção, as quais inevitavelmente se revelariam quando o povo é chamado a participar diretamente da vida política. Assim, exatamente por desconfiar-se da atuação direta do povo, sustenta-se que os indivíduos devem cuidar da sua vida privada, delegando o exercício do mister público à classe política, através do voto. O objetivo aqui é inverso ao que antes se expôs: intenta-se, especialmente, "acabar com a revolução", ou mais especificamente, com o terror imposto no período jacobino, trazendo estabilidade às instituições políticas. Logra-se, então, obter um modelo em que o povo ou nação perde a sua autônoma caracterização, já que ganhará forma unitária apenas com o surgimento das instituições representativas estatais.

Do exposto, vê-se que a Revolução Francesa fez-se vítima de uma verdadeira antítese mal resolvida entre versões radicais das democracias direta e representativa, ou, em outras palavras, entre um permanente exercício do poder constituinte do povo e uma espécie de soberania dos poderes constituídos: a primeira enfatizava a necessidade de legitimidade democrática dos atos do poder público, exigindo a participação direta do povo; a segunda priorizava a estabilidade e a continuidade das instituições políticas e, para tal desiderato, negava ao povo uma cidadania ativa. A consequiência desse profundo antagonismo foi a falta de equilíbrio entre as exigências igualmente relevantes de legitimidade e de estabilidade na condução da coisa pública, como se constata da degeneração desses modelos, respectivamente, em voluntarismo político e estatalismo.

Quanto ao primeiro, saliente-se que o recurso constante à vontade constituinte do povo subordina toda a estrutura política do Estado - órgãos públicos, direitos individuais e

\footnotetext{
${ }^{65}$ Considerando a realidade do voto censitário, e, via de conseqüência, a representação homogênea da burguesia no Legislativo, essa situação não era nada reconfortante às demais classes sociais, i.e., aos sanscullotes.
} 
Constituição - a interesses fugazes, causando óbvia insegurança e instabilidade, além de negar aos direitos individuais a sua conatural função de trunfo do indivíduo em face das deliberações políticas ordinárias. ${ }^{66} \mathrm{O}$ resultado é que a tutela e a própria definição dos direitos hão de flutuar ao sabor das contingências da vontade política momentânea, como nos confirma a cristalina dicção do Art. 28 da Constituição Jacobina de 1783, verbis: "Um povo tem sempre o direito de rever, reformar e de mudar sua Constituição. Uma geração não pode sujeitar às suas leis as gerações futuras."

Com a impossibilidade demográfica e territorial de implantarem-se democracias diretas na grande maioria dos modernos Estados-Nação, afigura-se natural que o modelo da representação política, em que pese às objeções de Rousseau contidas no Contrato Social, haja se afirmado como necessário à viabilização do modelo democrático para além das experiências pretéritas no âmbito das Cidades-Estado (v.g.: Grégia antiga e Itália renascentista). ${ }^{83}$

É exatamente a atribuição ao Parlamento da prerrogativa de revelar a vontade geral, considerando-se a lei empírica instrumento, por excelência, da soberania da nação ${ }^{67}$ e da razão humana, que marcará profundamente o modelo político-institucional prevalecente no âmbito da Europa Continental do século XIX ao segundo pós-guerra (Estado de Direito legalista). De fato, o conceito moderno-iluminista de lei, concebido por Rousseau e desenvolvido por Kant, sobre considerar a lei expressão concomitante da vontade do povo e dos imperativos da razão, vislumbra nessa espécie normativa a única forma de manifestação da soberania, reconduzindo as atividades estatais à criação e à aplicação do direito, à dicotomia função legislativa versus função executiva. Ora, parece claro que, desta hierarquização funcional decorre correlata

\footnotetext{
${ }^{66}$ FIORAVANTI, Maurizio. Los Derechos Fundamentales - Apuntes de la Historia de las Constituciones, especialmente p. 67.83

DAHL, Robert. Democracy and its critics. New Haven: Yale University Press, 1989; HARIOU, André. Droit Constitutionnel et Institutions Politiques. Paris: Éditions Montchrestien, 1972, p. 50.

${ }^{67}$ Como anota Burdeau, a soberania pertence à Nação, que se consubstancia em pessoa jurídica distinta dos indivíduos que a integram, de modo que a sua vontade não será obtida pela soma de vontades individuais, mas pela emissão da vontade da própria Nação, cabendo ao Corpo Legislativo expressá-la. V. BURDEAU, Georges. Ob. cit., p. 299. Acrescenta Hariou que, em França, prevalece a tese de que a noção unitária de Nação, e não propriamente os indivíduos isoladamente considerados, preexiste ao Estado. Aprofundando tal conceito, o Professor da Universidade de Paris salienta que os teóricos franceses inserem no conceito de Nação, não apenas os elementos relativos à raça, língua, religião, etc. (típicos do conceito alemão de soberania), mas também elementos espirituais (sentimento de pertencimento ao mesmo grupo), históricos (participação dos ancestrais nos mesmos eventos históricos), a comunhão de interesses entre os nacionais, etc. HARIOU, Georges. Op. cit., p. 91 et seq.
} 
hierarquia entre os órgãos estatais, de maneira a conceber-se a supremacia do Parlamento e da lei em relação aos poderes Executivo e Judiciário e aos seus respectivos atos. Essa relação superior-subalterno entre os órgãos do Estado implicará, naturalmente, um modelo políticoinstitucional cuja nota distintiva é o monismo do poder legislativo, na medida em que todo o poder político efetivo estará concentrado no Parlamento.

Assim, a própria separação orgânico-funcional dos poderes é colocada a serviço da supremacia do Legislativo e da lei, visto que a tripartição das funções estatais em legislativaexecutiva-jurisdicional e a sua concessão aos órgãos homônimos destinam-se a garantir que as funções executiva e jurisdicional se limitem à aplicação das leis, já que tais normas, mercê da sua origem democrática e da sua estrutura genérica e abstrata, veiculariam garantias inequívocas da soberania popular e da razão. Ora, se as leis têm essa especial dignidade, a consequiência natural é a impossibilidade de elas cometerem abusos, de modo a afastar qualquer mecanismo de limitação do Poder Legislativo por outros órgãos estaduais. Tais mecanismos interorgânicos de controle, e, notadamente, o mais importante deles, o controle jurisdicional de constitucionalidade, eram considerados ofensivos ao princípio da separação de poderes segundo tal formulação democrático-radical, a qual apenas toleraria que a função legislativa fosse limitada por débeis instrumentos de fiscalização intra-orgânicos (v.g.: bicameralismo, maioria parlamentar versus oposição, etc.) e extra-estaduais, sobretudo o controle político exercido pelo eleitorado. ${ }^{68}$

Tal arranjo institucional, sobre concentrar todo o poder político efetivo no Parlamento (relegando aos demais "poderes" uma tarefa de mera execução da lei), carece de efeito moderador em relação ao exercício do poder público, de modo que a sua distância em relação à separação de poderes como freios e contrapesos é abissal, porquanto nesse último modelo a finalidade primeira é a limitação do poder estatal através da sua fragmentação em órgãos independentes.

A realidade, contudo, viria a confirmar a perspectiva liberal de que um alargamento desta monta dos poderes de órgão do Estado, ainda que democraticamente legitimado pelo voto, causaria sério risco à tutela dos direitos individuais. Com efeito, tal constatação adveio quando descortinada a visão mitificada que o Estado de Direito legalista apresentava acerca das

\footnotetext{
${ }^{68}$ Ver, por todos, PIÇARRA, Nuno. A Separação de Poderes como Doutrina e Princípio Constitucional.
} 
potencialidades da lei e do legislador, construída com lastro na justificação da incondicional obediência à lei empírica a partir dos poderosos argumentos que embasam a lei racional, ou seja, a lei perfeita que seria produzida em um ambiente ideal de deliberação. ${ }^{69}$ Como visto, o conceito moderno-iluminista de lei associava o seu caráter intrinsecamente justo à sua origem democrática e ao seu conteúdo genérico e abstrato. Verificou-se, todavia, um afastamento desses requisitos de legitimidade no plano da praxis política, já que a atuação direta do povo, preconizada por Rousseau, foi substituída por um sistema representativo em que vigia o voto censitário, bem como o conceito de lei sofreu um processo de formalização, na medida em que essa espécie normativa passou a ser considerada tão-somente o ato produzido pelo Parlamento com observância do processo legislativo, abstraindo-se, portanto, de considerações a respeito da sua estrutura.

Do exposto, conclui-se que o conceito de vontade geral passou a atuar como instância de legitimação racional do que restara decidido por um Parlamento de proprietários, obtendo uma noção sacralizada da lei e das virtudes do Legislador, que acabava por justificar a obediência irrestrita dos indivíduos aos seus ditames, pois, por mais que o processo legislativo, na prática, se distanciasse da participação equânime e cooperativa do povo idealizada por Rousseau, e, por mais injustas, casuísticas e arbitrárias fossem as leis, dever-seia considerá-las como se proviessem da vontade uníssona do povo e dos imperativos da razão. Assim, a garantia dos direitos se limitara a um estéril postulado de reserva de lei, ou, em outras palavras, a "um único direito fundamental, o de ser tratado em conformidade às leis do Estado", ${ }^{70}$ promovendo uma espécie de desconstitucionalização e de dessubstancialização das liberdades civis, vez que, despidas de qualquer conteúdo necessário, a sua definição e eficácia jurídica estariam integralmente condicionadas à sanção do Estado soberano. Evidentemente que tal concepção, como notou agudamente Perez-Luño, ${ }^{71}$ despe os direitos individuais da sua conatural função de trunfos contra atos estatais arbitrários. ${ }^{89}$

\footnotetext{
${ }^{69}$ PRIETO SANCHÍS, Luis. Justicia Constitucional y derechos fundamentales., p. 74.

${ }^{70}$ FIORAVANTI, Mauricio. Los Derechos Fundamentales - Apuntes de la Historia de las Constituciones., p. 120 et seq..

${ }^{71}$ PEREZ-LUÑO, Antonio Henrique. Derechos Humanos, Estado de Derecho y Constituición, 5 ed. Madrid: Tecnos, 1995, p. 297. 89 A vinculação da validade e do conteúdo dos direitos individuais a uma normatividade superior às deliberações ordinárias dos representantes da Nação (i.e.: Declarações de Direitos, cujos princípios de justiça seriam inerentes à razão ou fruto de uma deliberação superior, de natureza constituinte) consistiria, ao ver dos juristas que contribuíram decisivamente para a construção do Estado de Direito legalista (notadamente,
} 
Note-se que o conceito de soberania da nação, e, via de consequiência, a atribuição à Assembléia representativa do monopólio da revelação da vontade geral do povo, denota a incorporação da soberania pelo Parlamento, acabando por dar azo à estranha "soberania dos poderes constituídos", que, precisamente por se revelar tipicamente estatalista, subverte a lógica individualista que inspirara o contratualismo revolucionário. Confira-se, a propósito, a feliz síntese de Prieto Sanchís:

É a apoteose do estatalismo: a soberania popular se dissolve em soberania estatal, o poder constituinte é diretamente assumido pelos poderes constituídos, o próprio povo é concebido como órgão do Estado que quando vota exerce uma função pública e, enfim, os direitos abandonam a sua condição de "reservas do direito natural" do indivíduo frente ao poder para converterem-se singelamente em direitos definidos pela lei mercê de um processo de autolimitação do Estado. ${ }^{72}$

Com efeito, a admissão de que o Parlamento possa, a qualquer tempo, exercer um poder soberano, coloca-o à margem da Constituição, com o status de autor do seu próprio poder, já que, na linha de Rousseau, não há de opor-se ao legibus solutus qualquer lei fundamental de índole obrigatória,. Verificando-se, portanto, uma confusão entre os poderes constituinte e constituídos, ${ }^{91}$ pois "os eleitos deixam de ser os representantes da nação soberana, para converterem-se em representantes soberanos da nação". ${ }^{92}$ A bem da verdade, o conceito de poder constituinte parece estar vinculado à superioridade e a pré-estatalidade da vontade do povo sobre a dos poderes constituídos. A efetiva realização desta dicotomia, por sua vez, parece vincular-se à idéia de rigidez constitucional, ou seja, à noção de que o povo, por

Raimond Carré de Malberg e Georg Jellinek) uma anacrônica reminiscência do contexto histórico das revoluções, o qual pressupunha, por um lado, "prestar a devida atenção a pressões contratualistas vindas da base da sociedade, e, por outro lado, criar uma tábua de valores que legitimasse os novos poderes públicos." V. JELLINEK, Georg.

Teoría General del Estado. Buenos Aires: Editorial Albatroz, 1973; CARRE DE MALBERG. Contribuition a la Théorie Génerale de L' Etat. Paris: Librairie de la Société du Recueil Sirey, 1920.

Superado no curso do século XIX, contudo, o contexto revolucionário (vide, por exemplo, a estabilidade obtida na Terceira República na França e no Segundo Império na Alemanha), não mais se colocava a necessidade de os atores privados e públicos se legitimarem em princípios de natureza político-constitucional. A sociedade regia-se pelo Código Civil e os poderes públicos se legitimavam pelo conceito ascendente de soberania do Estado, que recuperava o sentido estatalista da revolução francesa, na medida em que conferia ao Estado a condição de monopolizador da soberania política, cujo exercício se desvinculara, portanto, de qualquer influência de um sujeito pré-constituído, seja ele o monarca ou o povo. Assim, inexistindo qualquer referencial de legitimidade externo ao direito positivo, os direitos individuais eram vistos como atos soberanos de autolimitação do Estado, fundados, portanto, na soberania estatal, e dotados da certeza e da segurança que somente as leis do Estado, especialmente os Códigos e as normas do tipo regra, são capazes de prover. Ver, por todos, FIORAVANTI, Mauricio. Constituición. De la antiguedad a nuestros días, p. 113 et seq.

${ }_{72}$ PRIETO SANCHÍS, Luis. Op. cit., p. 78/79. 
intermédio de um processo deliberativo especial, dá a si uma Constituição, assim entendido o documento normativo superior que, ao fixar-lhes as competências, pretende limitar os poderes constituídos, inclusive o Legislativo. Tal pretensão ficaria completamente esvaziada caso os órgãos do Estado pudessem, por deliberação ordinária, sobrepor-se ao estatuído na Constituição. ${ }^{93}$

Este modelo padece, portanto, da mesma patologia que acometeu a democracia direta, na medida em que insere no âmbito do Estado um soberano, a quem, precisamente por se situar acima do direito positivo, compete alterá-lo quando e como bem entender. Disto resulta um permanente exercício do poder constituinte pelo Parlamento, pois a este departamento estatal caberia, à mingua de efetivos instrumentos de controle do exercício do seu poder, ${ }^{94}$ emitir, incessantemente, uma vontade ilimitada capaz de redefinir a forma de governo, as instituições políticas e o delineamento dos direitos individuais. O corolário natural do exposto é relegar-se a tutela e a definição dos direitos individuais ao sabor da instabilidade e das idiossincrasias da vontade política conjuntural, ${ }^{73}$ muito embora, por se consubstanciarem em prerrogativas inerentes à dignidade humana, hajam sido concebidos como garantias perenes oponíveis à satisfação de necessidades políticas momentâneas. Desta feita, a soberania popular não se estabiliza em um texto constitucional, mas, ao contrário, traduz-se em cada deliberação legislativa. A Constituição perde a sua tradicional função de equilibrar e limitar o poder com o escopo de proteger o cidadão, reduzindo-se a veículo da vontade livre e ilimitada do soberano, e, no essencial, a um só postulado: a observância irrestrita da lei. Cumpre repisar que a lei, por sua vez, era considerada instrumento, por excelência, da soberania e da razão humana, e que, portanto, buscava legitimidade em si própria, e não em parâmetros constitucionais substantivos.

Todavia, especialmente em sociedades em vias de uma efetiva democratização, mais factível do que confiar a tutela dos direitos "às luzes de um Legislador virtuoso" - que afinal estaria sujeito apenas aos constrangimentos da sua consciência, ao embate de forças divergentes no seio do Parlamento (bem menos intensos do que os atuais, em virtude do voto censitário prevalecente à época), e às contingências da história e do corpo de eleitores - parece

\footnotetext{
${ }^{73}$ Esta instabilidade constitucional é comprovada, por exemplo, pela história política francesa que, no período de 1789 a 1875, conheceu nada menos do que treze Constituições. Sobre a evolução histórica do constitucionalismo francês, ver, por todos, BURDEAU, Georges. Droit Constitutionnel et Institutions Politiques, Troisième Partie: Aperçu Sommaire D`Histoire Constitutionnelle de la France, p. 293/437.
} 
ser a adoção de um modelo de separação de poderes que substitua tal concentração de poderes no Parlamento pela sua atomização intra-estatal em órgãos independentes e relativamente equilibrados. Desta forma, a concessão de funções específicas e de instrumentos de controle mútuo a tais órgãos viabilizará que "o poder contenha o poder", segundo a clássica formulação de Montesquieu, a qual, partindo de um pessimismo antropológico diametralmente antagônico à profissão de fé do iluminismo francês nas virtudes do legislador, confere à balança entre os poderes a natureza de garantia institucional dos direitos fundamentais, em cuja ausência estes são reduzidos a meras declarações de intenção do soberano. Efetivamente, o Estado Constitucional, cujo núcleo essencial é composto pelos direitos individuais e pela separação de poderes, distingue-se pela negação de um soberano, de "um centro de poder ilimitado capaz de revogar a todo o momento os "direitos" que antes havia outorgado, sem que os seus destinatários os possam fazer valer perante outros centros de poder, especialmente os tribunais". 74

\footnotetext{
${ }^{74}$ PIÇARRA, Nuno. Op. cit., p. 189/190.

91 Tal fenômeno foi singularmente ilustrado pela assertiva de Guizot: "Se se pretende que existam ou devam existir dois poderes no seio da sociedade, um deles ordinário e outro extraordinário, um constitucional e outro constituinte, diz-se uma insensatez cheia de perigos e fatal (...) O governo constitucional é a soberania organizada. Estejam tranqüilos, senhores, nós, os três poderes constitucionais, somos os únicos órgãos legítimos da soberania nacional. Fora de nós não há mais que usurpação ou revolução.” Apud VEGA, Pedro de. La reforma constitucional y la problematica del poder constituyente. 5 reimpresión, Madrid: Tecnos, 2000, p. 44.

Excerto de G. Berlia, in "De la compétence constituante", in Revue de Droit Public, apud VEGA, Pedro de. Op. cit, p. 231. 93 Vale ressaltar que a noção de rigidez constitucional não integrava o modelo-padrão de Constituição no Estado de Direito legalista, pois prevaleciam à época as ditas Constituições flexíveis. É da lavra de James Bryce a tradicional distinção entre as Constituições Flexíveis e Rígidas: nas primeiras, conforme o preciso escólio de Canotilho, "as leis constitucionais" só diferem das demais leis pela matéria, mas não pela hierarquia, já que o procedimento apto a produzi-las é idêntico, inexistindo óbices a que as normas constitucionais sejam alteradas a qualquer tempo pela autoridade legislativa ordinária. Assim, no caso de norma constitucional e lei superveniente entrarem em conflito, prevalece a última, precisamente por ser posterior àquela. De efeito, inexistindo supremacia, o conflito há de resolver-se mediante o critério cronológico. Já as Constituições Rígidas se distinguem pela supremacia hierárquica que ostentam em face das leis em geral, mercê de sujeitarem-se a processo de reforma mais rigoroso do que o atinente à produção de leis, de maneira que, na hipótese de conflito entre "lei constitucional" e lei ordinária, prevalece a primeira, pois, embora cronologicamente anterior, goza de maior hierarquia. V. BRYCE, James. Constitutiones flexibles y Constitutiones rígidas. Madrid, 1963; CANOTILHO, José Joaquim Gomes. Direito Constitucional. Coimbra: Almedina, 1992.

Ainda que antes do segundo pós-guerra haja experiências de submissão de Constituições a um procedimento mais dificultoso do que o legislativo ordinário, cumpre notar que a ausência do controle jurisdicional da constitucionalidade das leis e atos normativos dificultava a afirmação do princípio da supremacia da Constituição em sua vertente hierárquico-normativa, segundo a qual as normas constitucionais gozam de superior hierarquia jurídica em relação às demais normas jurídicas, de modo que, verificando-se o conflito entre as últimas e as primeiras, as normas infraconstitucionais contrárias à Constituição seriam consideradas inválidas.

94 Como visto, considerava-se o controle jurisdicional de constitucionalidade atentatório à separação de poderes, concebida como arranjo institucional de garantia do primado da lei. Por outro lado, para além de confiar-se nas virtudes do legislador no que concerne à elucidação da vontade do povo e dos imperativos da razão, o Estado de
} 
Ao revés, no âmbito de um Estado Constitucional a soberania popular tende a ser exercida mediante a edição de um documento normativo dotado de superior hierarquia, em cujo âmbito são definidos os poderes juridicamente limitados dos órgãos estatais - competências. Substitui-se, portanto, o monismo do legislador pelo pluralismo dos poderes constituídos, todos subordinados à partilha constitucional de competências e dotados de instrumentos de recíproca fiscalização, de forma a impedir que um deles possa, por si só e de modo ordinário, alterar o disposto na Constituição, circunstância que denotaria a incorporação da soberania por poder constituído, e, por conseguinte, a convolação dos direitos individuais em meras tolerâncias, em singelos atos de autolimitação do Estado. ${ }^{75}$ Neste viés, parece prestar bom serviço à compatibilização dos conceitos de soberania popular e de supremacia da Constituição, sobretudo em sociedades em via de democratização, que o poder constituinte do povo, após editada a Constituição, retire-se das diuturnas atividades estatais, permanecendo na sociedade em estado de latência . "Criada a constituição, a ela caberá a supremacia, não havendo lugar a poderes à margem, acima ou fora dela. Só assim se poderá falar de Estado de Direito. Cada poder constituído apenas pode o que a constituição lhe permitir."76

Direito legalista conferia a soberania à nação, enquanto realidade histórico-natural, e não propriamente ao povo, concebido como conjunto unitário de indivíduos. Assim, à acusação de voluntarismo legislativo opõe-se uma tentativa de desdramatização da hipótese, argumentando-se que o legislador, não obstante soberano, não poderá nunca reduzir os espaços das liberdades civis para além do limite fixado pelo desenvolvimento histórico da nação. Aduz Fioravanti que "se a sociedade nacional se desenvolve em sentido liberal, de progressiva afirmação e extensão das liberdades civis e políticas - como os protagonistas daquele tempo acreditavam firmemente, animados por uma filosofia otimista da história e do progresso - o Estado deve seguir esta tendência, refletindo-a pontualmente na legislação. Se assim não fizesse, converter-se-ia rapidamente num corpo estranho, que a comunidade nacional rechaçaria." FIORAVANTI, Maurizio. Constituición. De la antiguedad a nuestros días, p. 123. Todavia, relegar-se a tutela dos direitos tão-somente ao controle extra-estadual dos eleitores ou a um determinismo histórico, salvo em contextos particularíssimos (como, i.e., o inglês, à luz do que se expôs no precedente item) parece perigoso, notadamente em países cuja maturidade política e desenvolvimento sócioeconômico não hajam atingido patamares elevados. Sustentar tal tese no bojo de um sistema eleitoral onde o voto era censitário soa, todavia, a um escárnio, a uma verdadeira tentativa de encobrir-se, sob o pálio da unidade histórica da nação, a homogeneidade ideológica de um Parlamento de proprietários, inviabilizando, ao fim e ao cabo, qualquer instrumento concreto de revisão das suas decisões. De qualquer sorte, com a progressiva universalização do sufrágio e o conseqüente surgimento dos partidos de massa, será muito mais complicado reconhecer nos legisladores espelhos fiéis da nação e da história, parecendo mais factível conceber a lei como fruto da vontade política de uma maioria vencedora de um processo político cada vez mais contratualizado, circunstância que reforça, a mais não poder, a necessidade de serem estabelecidos limites constitucionais à atividade legiferante. V. FIORAVANTI, Maurizio. Op. cit., p. 124/125.

${ }^{75}$ PIÇARRA, Nuno. Op. cit., p. 195 et seq..

${ }^{76}$ Ibid., p.

197. 99

Ainda que mitigada ou postergada pela redução do demos à classe dos proprietários e pelo embate de legitimidades monárquica e democrática, já que remanescia a forma de governo monárquica. 
A consequiência de tudo o quanto se expôs é a debilidade do Estado de Direito legalista na proteção dos direitos individuais, especialmente na sua tradicional acepção de trunfos contra a arbitrariedade estatal, tendo em vista a adoção de um modelo institucional estatalista e concentrador do poder soberano em um só órgão estatal. Cuida-se, enfim, de um regime marcado pela democracia ${ }^{99}$ sem constitucionalismo, na medida em que há nítida prevalência da noção de soberania sobre mecanismos institucionais destinados a limitação do poder com vistas à proteção do indivíduo. ${ }^{77}$

5 Constitucionalismo e democracia reconciliados: bases teóricas e construção do modelo norte-americano de Supremacia da Constituição e de controle de constitucionalidade.

Conforme salienta, com a habitual propriedade, Maurizio Fioravanti, o elemento-chave para o entendimento da raiz da diferença acerca da forma de proteção dos direitos individuais nos EUA e na França reside no exame da realidade contra a qual os revolucionários norteamericanos e franceses se insurgiram, e não na letra das respectivas Constituições e Declarações de Direitos, as quais apresentam evidentes similaridades quanto ao conteúdo dos direitos e a sua fundamentação jusnaturalista. Ressaltou-se no capítulo precedente, que a tutela dos direitos individuais na França pressupunha a superação da pluralidade intrincada de situações de privilégio do antigo regime por uma ordem jurídica fundada na liberdade e na igualdade formal entre os cidadãos. ${ }^{78}$ A necessidade de uma transformação social tão profunda implicou, naturalmente, o fortalecimento do Legislador recém-dotado de legitimidade democrática (para os padrões da época, que coonestava com a redução do demos aos proprietários), não se cogitando da sua limitação por uma lei fundamental.

Já nos EUA, os direitos individuais foram opostos ao Parlamento inglês em razão de um alegado exercício ilegítimo e abusivo das suas competências, notadamente no que concerne à instituição de tributos sobre os colonos, independentemente da aprovação das assembléias locais que os representavam..$^{79}$ Os colonos norte-americanos não se consideravam representados

\footnotetext{
${ }^{77}$ FIORAVANTI, Maurizio. Constituición. De la antiguedad a nuestros días, p. 110.

${ }^{78}$ FIORAVANTI, Mauricio. Los Derechos Fundamentales - Apuntes de la Historia de las Constituciones, p. 82.

${ }^{79}$ V. COOLEY, Thomas. Princípios Gerais de Direito Constitucional nos Estados Unidos da América. Campinas: Russel, 2002, p. 17 et. seq.
} 
pelo Parlamento inglês, mas pelas Assembléias coloniais cujos membros não eram apenas eleitos por eles, mas considerados concretos mandatários dos seus interesses.

Note-se que os colonos norte-americanos reputavam-se herdeiros da tradição de luta dos ingleses pela aquisição de direitos individuais, utilizando-se da proteção conferida pela constituição histórica inglesa aos bens e à liberdade dos seus súditos em face do próprio Parlamento britânico - especialmente a fórmula no taxation without representation -, com o intuito de obstaculizar o governo de imiscuir-se no patrimônio dos seus súditos sem que estes, através dos seus representantes, consentissem.

Vale ressaltar que a alusão aos direitos dos Englishmen vem acompanhada da nova roupagem que lhes foi conferida por um jusnaturalismo racionalista de inspiração lockeana. Embora não haja sensível distinção de conteúdo entre os direitos proclamados pelos colonos e os historicamente incorporados ao patrimônio jurídico dos ingleses, os primeiros assumiram um sentido próprio, qual seja, o de situações jurídico-subjetivas de liberdade e igualdade ostentadas pelos indivíduos no Estado de Natureza, cuja conservação e tutela são confiadas ao Estado Social quando da sua instituição. Erigem-se os direitos individuais, portanto, à condição de causa e de justificação de todo o poder político. ${ }^{80}$

Todavia, o contexto histórico supra aludido não poderia jamais levar os norteamericanos a confiarem a tutela dos seus direitos naturais a um legislador soberano, circunstância que afastou o modelo político dos EUA da soberania parlamentar que se instalara em França. Parece correto afirmar-se que, enquanto a "revolução francesa confia os direitos e liberdades à obra de um legislador virtuoso, que é assim considerado por sua alta representatividade do povo ou da nação, para além das facções e dos interesses particulares, a revolução americana desconfia das virtudes de todo o legislador - também do eleito democraticamente - e, assim, confia os direitos e liberdades à Constituição, é dizer, à possibilidade de limitar o legislador a uma norma de ordem superior". ${ }^{81}$ Efetivamente, é nota distintiva da revolução norte-americana o temor da atuação ilegítima e arbitrária dos poderes

\footnotetext{
${ }^{80}$ PRIETO SANCHÍS, Luis. Op. cit., p. 41. A propósito, a Declaração de Independência dos EUA, de 04 de julho de 1776, é cristalina: "Consideramos as seguintes verdades como auto-evidentes, a saber, que todos os homens são criaturas iguais, dotadas pelo seu Criador de certos direitos inalienáveis, entre os quais a vida, a liberdade, e a busca da felicidade. É para assegurar estes direitos que os governos são instituídos entre os homens, sendo seus justos poderes derivados do consentimento dos governados" (grifei). Apud COMPARATO. Fabio Konder. Op. cit. p. 103.

${ }^{81}$ FIORAVANTI, Maurizio. Op. cit., p. 82.
} 
constituídos (especialmente do Legislativo, tido como o mais poderoso deles), no que concerne à incorporação da soberania do povo ou à usurpação de competências uns dos outros. A tendência, por conseguinte, não é a de confiar ao Legislador a tutela e a definição dos direitos individuais, mas a de vislumbrar na preeminência desses direitos um verdadeiro limite ao legítimo exercício da função legislativa, na medida em que - repise-se - a irresignação dos colonos norte-americanos referia-se ao prejuízo que a onipotência do Parlamento inglês causara aos seus direitos. ${ }^{82}$

Desse modo, conferiu-se a tutela dos direitos individuais a uma Constituição, assim entendido o documento legislativo escrito que, exatamente por se revelar fruto do poder constituinte do povo, goza de superioridade hierárquica em relação às deliberações dos poderes constituídos. Daí se infere que o conceito norte-americano de poder constituinte apresenta-se, desde a sua gênese, vinculado às idéias de rigidez constitucional e de limitação do poder com a finalidade de proteger o indivíduo, porquanto a Constituição se consubstancia em um conjunto de normas cuja insuscetibilidade de supressão por maiorias eventuais se justifica ante o escopo de colocar os direitos individuais a salvo do arbítrio dos poderes constituídos. ${ }^{83}$

Se todo o poder emana do povo, as autoridades públicas em geral, sendo meros mandatários, não podem se voltar contra as normas estatuídas pelo titular da soberania (mandante), cristalizadas no texto constitucional. ${ }^{84}$ Saliente-se que a vinculação da supremacia da Constituição à tutela dos direitos individuais, ao estabelecer o pertencimento de princípios de justiça a uma norma superior intangível aos poderes constituídos, revela nítida transposição à ordem político-constitucional da pretensão jusnaturalista de impor-se ao direito positivo.

Todavia, o conceito norte-americano de poder constituinte, para além da noção de governo moderado ao qual estava historicamente vinculado, contém claramente a noção de

\footnotetext{
${ }^{82}$ Cf. MADISON, James. O federalista, n. 53. Campinas: Russell, 2003. p. 332.

${ }^{83}$ FIORAVANTI, Maurizio. Op. cit.,.p. 90.

${ }^{84}$ Nesta esteira, salienta Madison: "O povo é a única fonte de poder, sendo dele que provém a Carta Constitucional, segundo a qual se distribuem os poderes dos diferentes ramos do governo (...)”. E, de forma ainda mais enfática: “A importante distinção, tão bem compreendida na América, entre uma Constituição estabelecida pelo povo e inalterável pelo governo, e uma lei baixada e alterável por este, parece ter sido menos observada e compreendida em qualquer outro país". MADISON, James. O Federalista, n. 49 e 53, p. 313 e 331/332.

${ }^{108}$ PRIETO SANCHÍS, Luis. Op. cit., p. 49/50.

${ }^{109}$ PRIETO SANCHÍS, Luis. Op. cit., p. 41/42.
} 
soberania popular, reconhecendo, portanto, o poder político originário e soberano de indivíduos livres e iguais disporem acerca das normas fundamentais que estruturarão o Estado e disciplinarão a vida em sociedade. O objetivo da Constituição seria duplo: garantir os direitos e instituir o governo. Enquanto os direitos seriam fatos naturais, inerentes à razão e autoevidentes, a estrutura do governo, segundo a teoria do contrato social, seria eminentemente artificial, porquanto decorrente da vontade política do corpo constituinte de cidadãos. ${ }^{108}$

Do exposto, pode-se concluir que a luta pela afirmação da superioridade dos direitos individuais sobre os órgãos do Estado, marcante em seu processo de independência, criou no constitucionalismo norte-americano uma ambiência favorável à obtenção de uma solução conciliatória entre duas tradições políticas que andavam separadas, quais sejam: as noções de governo limitado por direitos individuais e de soberania popular, enfatizadas, respectivamente, por constitucionalistas e democratas. ${ }^{109} \mathrm{Um}$ exame mais cuidadoso dos fundamentos da afirmação da supremacia da Constituição na América afigura-se relevante para a adequada compreensão dessa assertiva.

A dualidade lei constitucional e lei ordinária, fruto, respectivamente, da vontade do povo e da vontade dos poderes constituídos, deve-se à circunstância de a primeira resultar de um processo deliberativo diferenciado, seja quanto à sua origem e ao procedimento observado, seja no tocante à sua qualidade intrínseca.

Pois bem. Quando a Assembléia de Massachusetts elaborou a Constituição do respectivo Estado, defrontou-se com a crítica generalizada - veiculada principalmente nas

town meetings ${ }^{85}$ - de que carecia de legitimidade para tanto, tendo em vista que, destinandose o documento constitucional a atribuir aos três poderes do Estado - inclusive ao Legislativo - as suas competências, limitando, portanto, a sua atuação aos ditames constitucionais, parece natural que a Constituição provenha de uma autoridade superior, distinta dos órgãos do Estado. Diante do malogro da iniciativa da referida Assembléia, em 1779 foi eleita uma Convenção com a finalidade específica de elaborar uma Constituição, a qual foi aprovada pelas referidas town meetings em 1780.

\footnotetext{
${ }^{85}$ Cuidava-se de reuniões realizadas nas cidades da Nova Inglaterra, revelando a prática de participação direta do povo nos assuntos de interesse coletivo que ali se estabelecera.
} 
A experiência das Constituições estaduais, iniciada pela Carta de Massachusetts, estabeleceu o procedimento-padrão para a manifestação do poder constituinte do povo na América: "em primeiro lugar, a eleição de delegados a uma convenção especialmente destinada à elaboração de uma Constituição; em segundo lugar, a adopção expressa de uma constituição escrita pela convenção; em terceiro lugar, a ratificação do projecto de constituição pelo povo". 86

É bem de ver que, na experiência política inglesa do século XVIII, o termo “convention" designava um Parlamento irregularmente constituído, sendo que a mais importante delas foi a que reuniu Lordes e Comuns sem a presença do Rei e redundou na Revolução Gloriosa. ${ }^{112}$ Foi precisamente a "irregularidade" jurídico-formal das Convenções Constitucionais e a participação efetiva do povo (i) na eleição dos seus membros com a finalidade específica de elaborar um projeto de Constituição, e (ii) na ratificação do produto da sua deliberação, que levou a considerar-se o procedimento acima aludido como o que melhor expressava o poder constituinte do povo, distinguindo os atos políticos extraordinários, resultantes da manifestação episódica do povo, das leis ordinariamente editadas pelo

Parlamento, mercê da manifestação de vontade dos seus representantes. ${ }^{87}$

Todavia, como antes salientado, a superioridade da manifestação das convenções constitucionais sobre as do Parlamento e, via de conseqüência, da Constituição sobre as leis não decorre apenas do consentimento do We the people, a que se refere a Constituição americana, mas também do ambiente especial de deliberação presente quando o povo é chamado a atuar ativamente no processo político. A propósito, o modelo do constitucionalismo norte-americano distingue-se pela adoção de uma concepção dualista da democracia, porquanto promove uma clivagem entre política constitucional e ordinária. Com efeito, o contexto político que marcara a criação da Constituição dos EUA caracterizou-se pela comunhão na sociedade de uma sensação "de perigo que conteve os sentimentos mais inamistosos e que propiciou a união e a concórdia; de uma integral confiança do povo em seus líderes patrióticos (...)”. ${ }^{114}{ }_{-}^{115}$

\footnotetext{
${ }^{86}$ BRITO, Miguel Nogueira de. A constituição constituinte: ensaio sobre o poder de revisão da constituição,p. 31112 V. ACKERMAN, Bruce. We The People - Transformations. Cambridge: The Belknap University Press, 1998. ${ }^{87}$ BRITO, Miguel Nogueira de. A constituição constituinte: ensaio sobre o poder de revisão da constituição, p. 32. Ackerman, a propósito, salienta que a forma mais alta de expressão política não se acha em Assembléias regularmente constituídas com base na lei preexistente, mas por Convenções que, embora "formalmente irregulares", precisamente por contarem com o apoio popular, vocalizam a vontade do povo. V. ACKERMAN, Bruce. We the people - Foundations. Cambridge: The Belknap University Press, 1991, p. 174 et. seq.
} 
Assim, nos momentos de política constitucional (constitucional politics) nota-se não apenas o exercício de uma cidadania ativa, mas, especialmente, que o povo logra desvencilharse da sua tendência natural de perseguir os seus interesses particulares e imediatos, de agir passional e irracionalmente, atuando, ao revés, tendo em vista a realização do bem comum e de expectativas de longo prazo. Em poucas palavras: nos raros momentos constitucionais, o ambiente de insegurança e incerteza que os cerca torna possível a concretização da aspiração republicana da virtude ética dos cidadãos em sua atuação política.

Assim, este processo deliberativo eticamente superior retira princípios básicos de justiça do alcance de maiorias conjunturais, as quais, atuando no âmbito da política ordinária (normal politics), estarão sujeitas a sucumbir à atuação auto-interessada, em prejuízo aos direitos das minorias. ${ }^{88}$

Nada obstante, o objetivo principal de toda a teorização contida nos escritos reunidos no Federalista não é o de justificar racionalmente a supremacia da constituição, ou a forma como

\footnotetext{
${ }^{88}$ Este modo de agir se revela no conceito de facção, a qual, segundo Madison, seria: "um grupo de cidadãos, representando quer a maioria, quer a minoria do conjunto, unido e agindo sob um impulso comum de sentimentos ou interesses contrários aos direitos dos outros cidadãos ou aos interesses permanentes e coletivos da comunidade". Salienta, ainda, que esta forma egoística de agir seria inerente à natureza humana em um regime de liberdade.MADISON, James. O Federalista, n. 10. Op. cit., p. 78.

114 MADISON, James. O Federalista, n. 49. Op. cit. p. $314 / 315$.

115 Este modelo dualista, embora reconstruído recentemente por Ackerman, em festejada formulação, consiste em um dado da história constitucional norte-americana, e é constitutiva do pensamento dos Federalistas, notadamente do de Madison. V. BRITO, Miguel Nogueira de. Op.cit., p. 39/40.

A propósito, Bruce Ackerman defende que a Constituição é resultado de um processo de deliberação eticamente superior, não necessariamente coincidente com o ato formal de sua elaboração, pois, nos períodos de excepcional excitação cívica nos quais são irrompidos tais processos, os grupos afastar-se-iam dos seus interesses particulares, e perseguiriam o superior interesse público.

O Professor de Yale funda, portanto, a supremacia da Constituição na circunstância de ela ter sido fruto de um processo deliberativo eticamente superior ao ordinário e no seu conteúdo intrínseco, de maneira que este fundamento moral justificaria, à luz do princípio democrático, a supremacia da Constituição. À luz do quanto se expôs anteriormente, nítido se afigura que este republicanismo cívico busca inspiração no pensamento de Madison. Ressalve-se, apenas, que a defesa de uma sucessão de distintas ordens constitucionais materiais sob a égide da mesma Constituição formal, melhor se adequa ao caráter sintético das Constituições-Garantia, como a estadunidense que, sem substancial alteração em seu texto, comportou profundas modificações durante os seus mais de dois séculos de vigência. Neste particular, cite-se, por exemplo, a evolução do tratamento conferido aos afroamericanos (escravidão, doutrina do equal but separate, igualdade formal, igualdade material e políticas de ação afirmativa), e a progressiva universalização do sufrágio (neste caso e na abolição da escravidão houve alterações formais), a superação de um radical liberalismo econômico pelo advento do Estado do Bem-Estar social (New Deal de Roosevelt), o movimento de proteção dos direitos civis promovidos pela Corte de Warren, etc. V. ACKERMAN, Bruce. We the people - Foundations.
} 
ela se compatibiliza com as exigências tendencialmente antagônicas de governo limitado e de soberania popular. Tendo em vista o assentamento social destas concepções, ${ }^{89}{ }^{90}$ busca-se conceber instituições que, não apenas se guiem pela soberania popular e pela moderação governamental, mas que logrem sanar os efeitos da política praticada por homens que não são $\operatorname{anjos}^{118}$ aproximando, tanto quanto possível, o resultado das políticas ordinária e constitucional, ou seja, a deliberação ordinária de políticos profissionais daquela oriunda da ocasional participação direta e virtuosa do povo. ${ }^{119}$

Ao lado da transposição dos direitos individuais para o domínio de uma Constituição rígida, a previsão em seu bojo de um particular modelo de separação de poderes destinava-se também a aprimorar as deliberações políticas e a instituir um governo limitado. Os norteamericanos desconfiavam das virtudes cívicas do homem comum em condições ordinárias de deliberação, na linha do liberalismo político inglês do século XVII e em contrariedade à perspectiva republicana de Rousseau. ${ }^{91}$ Todavia, a alternativa que se extraía da experiência político-constitucional inglesa, qual seja, a busca de contenção do poder estatal através da sua fragmentação entre as forças sociais que atuavam no âmbito do Parlamento (governo misto), encontrava-se vinculada à divisão da sociedade em estamentos e, via de conseqüência, à busca de um equilíbrio entre princípios distintos de legitimação política (monárquico e representativo). Ora, tal realidade não era apenas teoricamente rejeitada, mas também inexistente à época nas treze colônias. De fato, apesar de reconhecer-se a divisão desta incipiente sociedade em classes sociais guiadas por interesses distintos (v.g.: comerciantes, profissionais liberais, fazendeiros, etc.), "na escala política (tais classes) estavam em pé de igualdade, e entre os seus membros não existiam distinções de ordem". ${ }^{92}$ Não se cogitava, portanto, de ordens aristocrática e monárquica sujeitas a regimes jurídicos e legitimidades

\footnotetext{
${ }^{89}$ VEGA, Pedro. Op. cit., p. 39.

VIEIRA, Oscar Vilhena. A constituição e sua reserva de justiça: um ensaio sobre os limites materiais ao poder de reforma. São Paulo: Malheiros, 1999, p. 53, utilizando-se da expressão de Madison no Federalista, n.

. Op. cit. 119 BRITO, Miguel Nogueira de.

Op. cit., p. 41.

91 Ver os dois antecedentes itens. Na esteira do exposto, salienta Laurence Tribe que os norte-americanos comungavam da concepção de que os direitos individuais seriam melhor protegidos pela fragmentação do poder em diversos entes estatais. Assim, construiu-se não apenas um modelo de repartição horizontal do poder entre Legislativo, Executivo e Judiciário, mas também um mecanismo da separação vertical do poder entre a União e os Estados-Membros (federalismo). V. TRIBE, Laurence. American Constitutional Law. New York: New York University Press, 2000 , p. 7.

${ }_{92}$ PIÇARRA, Nuno. Op. cit., p. 179.
} 
próprias. Ao contrário, cuidava-se de sociedade em cujo âmbito prevalecia a igualdade perante a lei e o princípio republicano como único instrumento de legitimação do poder político. ${ }^{93}$

Entretanto, à vista de persistir a necessidade de engendrarem-se arranjos institucionais destinados a conter o exercício arbitrário do poder estatal com o fito de proteger os direitos individuais, utilizou-se o método da balança entre os poderes em uma perspectiva institucional, na medida em que o escopo imediato terá residido em atingir-se, através da fragmentação do poder, equilíbrio e harmonia entre os "poderes constituídos" (Legislativo, Executivo e Judiciário, apenas reflexamente alcançando os grupos sociais). Neste viés, atribuiu-se a cada um deles, por intermédio de delegação constitucional do poder do povo, um rol de competências próprio e mecanismos de recíproca fiscalização, de sorte a evitar que um dos órgãos do Estado logre incorporar a soberania popular, ou que se imiscuísse em domínios constitucionalmente reservados a outros departamentos. Tais instrumentos de independência e de controle mútuo entre os órgãos estatais afigurar-se-iam necessários, ante a insuficiência de confiar a fiscalização da sua atuação apenas ao povo, ${ }^{94}$ que, embora seja a "única fonte legítima do poder", não pode exercer uma vigilância permanente sobre os seus delegados. ${ }^{95}$

Desta configuração do princípio da separação de poderes avulta (i) a prevalência da dimensão institucional sobre a político-social (o objetivo imediato é o equilíbrio entre os poderes do Estado e não entre as forças sociais) $;^{96}$ (ii) a sua inspiração liberal, tendo em vista a atomização intra-estatal dos núcleos de poder e os instrumentos de freios e contrapesos destinarem-se, precipuamente, à contenção do poder público; (ii) e a sua vinculação à noção de rigidez constitucional, porquanto, ao preconizar que nenhum dos departamentos estatais seja autor do seu próprio poder, pressupõe que as respectivas competências sejam-lhes atribuídas pela Constituição, enquanto documento normativo superior oriundo da vontade popular. Corolário natural deste último aspecto é a constatação de que a noção de poder constituinte emergente na América se revela significativamente distinta da prevalecente na França pósrevolucionária. Com efeito, a admissão de a soberania popular se estabilizar em um texto escrito, o qual constitui verdadeiro limite à ação dos poderes constituídos, afasta o modelo

\footnotetext{
${ }^{93}$ Nada obstante, como é notório, foram adotados (especialmente nos Estados do Sul) regimes escravocratas, para além do voto censitário, de modo que a prevalência da igualdade perante a lei e do princípio republicano deve ser temperada pela redução do demos à classe dos homens livres e dotados de propriedades.

${ }_{94}^{94}$ MADISON. James. O Federalista, N. 51.

${ }_{95}$ MADISON, James. O Federalista, N. 49.

${ }^{96}$ V. seção 3 in fine.
} 
americano tanto do voluntarismo da democracia direta, quanto do risco de incorporação da soberania pelos poderes constituídos, em cujos âmbitos, consoante salientado no precedente capítulo, não se admitia a "limitação" do soberano por uma lei fundamental.

$\mathrm{O}$ apelo à virtude do povo e a desconfiança a respeito da deliberação dos poderes constituídos, ínsitos à dualidade política constitucional versus política ordinária, poderia levar a crer que os norte-americanos aproximar-se-iam de um modelo de democracia direta análogo ao defendido pelos jacobinos, em que o povo é chamado a deliberar, direta e ordinariamente, a respeito dos assuntos de interesse coletivo. De fato, a "labareda democrático-radical" que se acendeu após a Declaração de Independência acabou por ser rapidamente apagada pela afirmação do governo republicano em detrimento do governo democrático ou popular, utilizando-nos da terminologia madisoniana. A propósito, Madison constatou que o governo republicano se destina a controlar a violência das facções que se verifica nos governos democráticos, sem, todavia, afastar-se dos princípios que lhe são caros (notadamente a soberania popular), como se verificara no modelo de democracia representativa presente no Estado de Direito Legalista.

Assevera Madison que é da natureza humana a atuação auto-interessada, de maneira que, em uma democracia pura, em que os cidadãos deliberam diretamente sobre os assuntos de interesse coletivo, prevalecerá no espaço público o espírito de facção, que se guia pela busca da satisfação de interesses e paixões particulares, criando um clima de animosidade mútua incompatível com o espírito de colaboração recíproca que deve prevalecer em uma República. Daí porque em uma democracia pura "não há cura para os males da facção", inexistindo mecanismos hábeis a proteger os direitos das minorias contra a propensão da maioria em usurpá-los. ${ }^{97}$

Apesar de o povo ser a fonte última do poder político, salienta Madison em resposta à proposta de Jefferson de revisão da Constituição a cada dezenove anos - formulada com o escopo de conceder às gerações direito de autogoverno idêntico ao da geração constituinte - que o reiterado apelo ao "poder constituinte do povo" causaria forte abalo à estabilidade das

\footnotetext{
${ }^{97}$ MADISON, James. Op. cit., n. 10, p. 80.
} 
instituições políticas. ${ }^{98}$. Com a restrição da participação direta do povo no processo político aos momentos constitucionais, cujo clima de incerteza e insegurança permitiria uma atuação dirigida ao interesse público, ${ }^{99}$ logra-se obter modelo que prestigia a soberania popular e evita a instabilidade ínsita ao recurso recorrente à vontade popular, rediscutindo incessantemente a autoridade dos órgãos do estado e conteúdos constitucionais essenciais, como os direitos fundamentais.

Enfatize-se que a busca por estabilidade não se fez à custa da soberania popular, como decorria do modelo estatalista de democracia representativa que marcou o Estado de Direito legalista, o qual acabou por gerar uma absorção da soberania pelos órgãos do Estado. Consoante destacado, é nota distintiva do processo de independência dos EUA a oposição a qualquer forma de estatalismo, de onipotência dos órgãos do Estado. A conciliação das exigências de soberania popular e de estabilidade dos poderes constituídos se tornou possível através da noção da Constituição como lei superior (higher law). Pois bem: reconhece-se ao povo um poder soberano, originário e ilimitado, cujo exercício não se prolongará indefinidamente, mas se estabilizará em um documento normativo escrito, editado no bojo de um processo deliberativo qualitativamente superior e que, por ser dotado de supremacia entre as fontes do Direito, limita os órgãos do Estado ao estatuído pela vontade superior do povo. ${ }^{100}$

98 Em suas palavras: “(...) a repetição desses apelos (ao povo) privaria a instituição daquele respeito que o tempo confere e sem o qual nem mesmo o melhor e mais livre dos governos manteria a necessária estabilidade". MADISON, James. O Federalista n. 49, p. 314.

${ }^{99}$ ACKERMAN, Bruce. We the people - Foundations, p. 176.

${ }^{100}$ Ackerman assevera que os Federalistas adotam uma concepção semiótica acerca da representação popular por intermédio de um texto escrito (Constituição). Isto porque o texto constitucional não considera o Parlamento a expressão real da vontade popular, o povo em si (como se poderia supor em uma perspectiva mimética), mas os seus meros representantes. A melhor forma de realização desse desiderato seria mediante a proliferação do número e das espécies de representantes do povo: "The House" representa o povo de uma determinada maneira, à vista da eleição direta dos seus membros, o Senado representa o povo de outra maneira, dada a seleção dos Senadores pelas legislaturas estaduais, e o Presidente representa o povo de uma terceira forma, tendo em vista a ua eleição pelo Colégio Eleitoral. Assim, o sistema constitucional confere a uns as virtudes que os outros não têm, competindo, v.g., à House refletir qualquer comoção popular, ao Senado um juízo abalizado, e ao Presidente uma ação enérgica e decisiva, impedindo que um grupo social ou órgão estatal possa se auto-proclamar o legítimo representante do povo. A bem da verdade, será o embate da pretensão de cada um dos Poderes de falar em nome do povo que conterá as vicissitudes da política ordinária, viabilizando uma deliberação mais qualificada. V. ACKERMAN, Bruce. Op. cit., p. 183 et. seq.

130 HAMILTON, Alexander. O Federalista n. 78,

p. 470 .

131 Ademais, não há que se falar em predomínio do Judiciário sobre os demais departamentos estatais, pois, além de ser o "mais fraco entre os poderes", na hipótese em tela o Judiciário se limita a preservar a vontade constituinte do povo da ação erosiva dos poderes constituídos. 
Garantida a estabilidade dos poderes constituídos pela definição das suas atribuições e limites em uma lei superior, a circunstância de esta norma suprema resultar da vontade do povo preserva a dualidade entre os poderes constituinte e constituídos. Não caberia, portanto, aos poderes constituídos (inclusive ao Parlamento) imiscuírem-se no âmbito de deliberação do povo, pois admitir o contrário significaria coonestar com a assertiva de que competiria aos poderes do Estado a definição das competências e limites aos quais deveriam estar sujeitos, em nítida confusão de papéis entre mandante e mandatário, entre titular da soberania e mero representante. $^{130}$

Ora, se a Constituição veicula delegação do povo aos poderes constituídos, inclusive ao Legislativo, tendo em vista o estabelecimento de um governo limitado, é corolário natural dessa pretensão a superioridade hierárquica das normas constitucionais sobre as leis, obstando que a legislatura altere a Constituição por meios ordinários. Assim, na hipótese de conflito entre Constituição e lei, a primeira, embora mais antiga, há de prevalecer, mercê de sua maior hierarquia, considerando-se a lei inconstitucional nula de pleno direito. Cuidando-se, ademais, de conflito entre normas jurídicas, tal atividade se insere no âmbito da interpretação das leis em sentido lato, domínio próprio de atuação do Poder Judiciário. ${ }^{131}$ Estes são os contornos gerais da teoria do controle judicial da constitucionalidade das leis, os quais, como se sabe, já se encontravam no clássico escrito de Hamilton, ${ }^{132}$ e vieram a ser empregados por Marshall no célebre acórdão proferido no caso Marbury v. Madison (1803). ${ }^{133}$

\section{Conclusão}

Do exposto na seção anterior, vê-se que o mecanismo norte-americano de separação de poderes confere ao Judiciário um papel significativamente mais destacado daquele que lhe foi conferido pelo Estado de Direito legalista, pois era natural que em um modelo de separação de poderes marcado pela supremacia do Legislativo não houvesse espaço para que o Judiciário 
procedesse à declaração da inconstitucionalidade das leis. Na América, contudo, tal atividade insere-se entre os mecanismos de freios e contrapesos, circunstância que evidencia a concessão de um poder efetivo ao Judiciário, bem como o objetivo de estabelecer uma relação de equilíbrio e harmonia que abranja não só o Legislativo e o Executivo, mas também o Judiciário, todos submetidos à Constituição, e predispostos a mutuamente se contrabalançar e, por conseguinte, a atuar de forma concertada e comedida.

Para além de uma desconfiança a respeito das virtudes da lei, e, inversamente, uma forte expectativa quanto à eticidade das deliberações constituintes, as tradições inglesas do commom law e da independência dos juízes contribuíram para a construção da doutrina norteamericana do controle judicial de constitucionalidade das leis. Neste particular, destaca-se o

magistério de Sir Edward Coke, no sentido de que os juízes teriam o dever de negar aplicação às leis que contraviessem a ancient commom laws and customs of the realm, assim entendido o conjunto de leis e direitos profundamente radicados na história do país, que ostentariam a condição de lei fundamental oponível mesmo às deliberações parlamentares. ${ }^{101}$ Ademais, a prática de o governo britânico, através de decisões do Privy Council, do Parlamento e da Coroa, invalidar as leis oriundas das Assembléias coloniais que contrariassem o direito inglês estimulou, por assim dizer, o judicial review. ${ }^{102}$

O modelo norte-americano, contudo, associou a atribuição de o Judiciário zelar pela intangibilidade de uma lei fundamental não aos costumes consolidados historicamente (Coke) ou puramente a imperativos da razão (jusnaturalismo), mas a uma deliberação superior do corpo constituinte de cidadãos, cristalizada no texto constitucional. A fundamentação da criação da Constituição em um ato de soberania do povo, todavia, não a despiu do conteúdo que o constitucionalismo historicamente lhe havia atribuído, qual seja o de um espaço destinado a harmonizar os poderes, de modo a evitar a formação de um soberano que pusesse em risco a proteção do indivíduo. Com efeito, a noção de que a soberania popular seria exercida no ato de edição do documento constitucional, prevalecendo a posteriori a supremacia

\footnotetext{
${ }^{101}$ FIORAVANTI, Maurizio. Constitución. De la Antiguedad a Nuetros Días, p. 67/68.

${ }^{102}$ NOWAK, John E.; ROTUNDA, Ronald D. Constitutional law, p. 10. James Thayer, em artigo clássico, aduz que o controle jurisdicional de constitucionalidade é um resultado natural dessa experiência anterior à Guerra de Independência. Substitui-se tão-somente o soberano: não mais o Parlamento inglês, mas o povo norte-americano (We the People). THAYER, James Bradley. The origin and the scope of the american doctrine of constitutional law. Harvard Law Review 129 (1893), p. 603.
} 
da Constituição, sujeitou os poderes constituídos aos seus ditames, evitando que um deles se arvorasse na condição de legibus solutus. ${ }^{103}$

Por outro lado, aprimorou-se a tradição britânica dos freios e contrapesos, ao enfatizarse a necessidade de equilíbrio e de fiscalização mútua entre os órgãos do Estado (incluindo-se o Judiciário neste arranjo) e não entre as forças sociais. A autoridade dos órgãos do Estado passou a fundar-se na vontade superior do povo contida na Constituição, não concorrendo, portanto, com o princípio republicano, outros mecanismos de legitimação (v.g.: monárquico e aristocrático). Ademais, ao serem entrincheirados na Constituição e terem a sua salvaguarda submetida ao Judiciário, órgão relativamente insulado do processo político, os direitos individuais foram retirados do alcance de pretensões usurpadoras das maiorias políticas conjunturais, conferindo-lhes certo grau de estabilidade. ${ }^{104}$

A par de considerar a separação de poderes e os direitos individuais elementos constitucionais essenciais, saliente-se a circunstância de a Carta de 1787 haver sido submetida a referendo popular e produzida num ambiente ideal de deliberação, que permitiu aos participantes, em alguma medida, desvencilharem-se dos seus interesses particulares em prol do bem comum. Do amálgama destes fatores, que evidencia a busca de um equilíbrio entre os ideais constitucionalista e democrático, parece lícito concluir, na esteira de Oscar Vilhena Vieira, que "(se) trata de uma teoria mais sofisticada de constituição, que fundamenta sua supremacia em um somatório de razões, que associa valores substantivos, modelo de deliberação e processo de ratificação - ou seja: conjuga justificações valorativas, de racionalidade procedimental e majoritárias." $" 138$

Uma forma sugestiva de ilustrar tal processo político-deliberativo qualitativamente superior consiste na utilização da noção de pré-compromisso constitucional. Tal idéia, que se notabilizou com a obra de Jon Elster, ${ }^{105}$ é bem ilustrada pelo conto mítico de Ulisses e as Sereias, relatado por Homero no Livro XII da Odisséia. Homero noticia que Ulisses, tendo sido

\footnotetext{
${ }^{103}$ Sobre a incorporação do conceito de Constituição pelo de soberania, ver o antecedente capítulo.

${ }^{104}$ Desde o surgimento do primeiro direito fundamental - a proteção contra a prisão arbitrária -, afigura-se patente a relevância da existência de um órgão estatal responsável por zelar, com independência, pela sua salvaguarda, notadamente em face da ação lesiva dos demais departamentos estatais, cumprindo ressaltar que, historicamente, coube aos tribunais tal função. PIÇARRA. Op. cit., p. 195/196. ${ }^{138}$ VIEIRA, Oscar Vilhena. Op. cit.,p. 58/59.

${ }^{105}$ ELSTER, Jon. Ulysses and the Sirens - Studies in rationality and irracionality. Great Britain: Cambridge University Press, 1979. A imagem também é usada por Oscar Vilhena Vieira para ilustrar especificamente a vinculação do poder de reforma às cláusulas pétreas. V. VIEIRA, Oscar Vilhena. Op. cit.
} 
advertido por Circê que, ao passar pela ilha das sereias acabaria por sucumbir ao seu canto irresistível, ordenou aos seus comandados que o amarrassem ao mastro, permitindo, assim, que não cedesse àquela tentação irresistível. ${ }^{106}$ Conforme salienta Daniel Sarmento: "o précompromisso de Ulisses, que limitou o poder de sua vontade no futuro para evitar a morte, poderia ser comparado àquele que se sujeita o povo, quando dá a si uma constituição, e limita seu poder de deliberação futura, para evitar que, vítima de suas paixões e fraquezas momentâneas, possa pôr em risco o seu destino coletivo."107

Os pré-compromissos constitucionais se consubstanciam em estratégias de autoincapacitação, extraídas dos pré-compromissos individuais - cogite-se, por exemplo, que pessoa com dificuldades de acordar cedo coloque seu despertador longe da cama, para evitar que o desligue e continue a dormir -, por meio das quais um indivíduo ou um povo, em um momento de lucidez, afasta a possibilidade de adotar decisões míopes a que estaria tendencialmente sujeito em momentos de debilidade da vontade ou de racionalidade distorcida, logrando, desta forma, afastar-se de tentações ou fraquezas e, via de conseqüência, atingir os seus verdadeiros interesses. ${ }^{108}$ Adaptando-se tal noção para as deliberações constitucionais, pode-se afirmar que o povo, quando elabora a sua Constituição, retira do poder ordinário de deliberação dos órgãos do Estado normas e valores reputados fundamentais, evitando que, no futuro, vítima das suas próprias fraquezas, venha a pôr em risco a tutela desses preceitos por ceder a pressões impostas por contingências políticas voláteis.

Diversas são as críticas dirigidas ao transplante dos pré-compromissos individuais para o domínio político-deliberativo. ${ }^{109}$ Dados os propósitos específicos do presente artigo, interessa-nos, por ora, tão-somente destacar que a retirada de normas e valores fundamentais de uma sociedade do dia-a-dia do processo político, através do seu entrincheiramento

\footnotetext{
106 “(...) atai-me com laços bem apertados, de sorte que permaneça imóvel, de pé, junto ao mastro, ao qual deverei estar preso por cordas. Se vos pedir que me desligueis, apertai-me com maior número de laços.” HOMERO. Odisséia, Livro XII. São Paulo: Nova Cultural, 2002, p. 161.

${ }^{107}$ SARMENTO, Daniel. Direito adquirido, emenda constitucional, democracia e reforma da Previdência. In: TAVARES, Marcelo Leonardo (org.). A reforma da previdência social: temas polêmicos e aspectos controvertidos. Rio de Janeiro: Lúmen Iuris. 2004. p. 11.

${ }^{108}$ BAYÓN, Juan Carlos. "Derechos, democracia y constitución”. In: LAPORTA, Francisco. Constitución problemas filosóficos. Madrid: Centro de Estudios Políticos y Constitucionales, 2003, p. 410. Ver, também, HOLMES, Stephen. Pre-commitment and the paradox of democracy. In: HOLMES, Stephen. Passions and Constraints - on the theory of liberal democracy. Chicago: University of Chicago Press, p. 134/178.

${ }^{109}$ Ver, por todos, a crítica formulada por Jeremy Waldron: WALDRON, Jeremy. Law and disagreement. Oxford: Oxford University Press, 2004, especialmente o capítulo 12, intitulado "Disagreement and Precommitment".
} 
constitucional, consiste em fenômeno que se generalizou a partir do segundo pós-guerra, com a afirmação na Europa Continental das idéias de supremacia hierárquico-normativa das Constituições, rigidez constitucional e de controle jurisdicional de constitucionalidade das leis e atos normativos, tendo se consolidado no quarto final do século passado, com a queda das ditaduras na América Latina e do comunismo no Leste Europeu ${ }^{110}$ Trata-se de inequívoca vitória do modelo de constitucionalismo norte-americano, ${ }^{145}$ podendo-se constatar que os constituintes contemporâneos comungam da perspectiva de que algum nível de rigidez constitucional se afigura pertinente para, sem prejuízo do ideal democrático, garantir a preservação da estabilidade das instituições políticas e de prerrogativas ligadas à dignidade humana.

Nada obstante, cumpre assinalar que as Constituições contemporâneas não se limitam a prever a estruturação do Estado, a separação dos poderes, e alguns poucos direitos fundamentais como limites ao poder público, como se dava nas Constituições-Garantia de que é exemplo clássico a norte-americana. Ao contrário, as Constituições típicas do neoconstitucionalismo predeterminam, em diversas intensidades, a regulação jurídica das mais diversas searas, como, p. ex., a economia, as finanças públicas, a seguridade social, as relações de trabalho, a cultura, o desporto, a comunicação social, a ciência, a tecnologia, a defesa do consumidor, da família, do meio ambiente, do patrimônio histórico-cultural, etc. A esse amplo conteúdo normativo soma-se a positivação não só de direitos a prestações estatais negativas (direitos de defesa), mas também de direitos a prestações estatais positivas (direitos prestacionais, v.g.: direito à educação, à saúde, à previdência e à assistência social), cuja satisfação normalmente pressupõe a implementação de custosas políticas públicas. ${ }^{111}$ Tais

\footnotetext{
${ }^{110}$ Para uma proficiente descrição deste fenômeno, ver ACKERMAN, Bruce. The rise of world constitutionalism, in Yale Law School Occasional Papers, Second Series, Number 3, Connecticut, 1997, p. 01/20; GINSBURG, Tom. Judicial review in new democracies: constitutional courts in asian cases. USA: Cambridge University Press, 2003. 145 Refere-se às idéias de supremacia hierárquico-normativa da Constituição, rigidez constitucional e controle jurisdicional de constitucionalidade, e não a características específicas do modelo norte-americano de controle de constitucionalidade, como o seu caráter difuso e incidental, pois é sabido que o modelo austríaco de controle de constitucionalidade concentrado e abstrato foi adotado, de forma pura ou combinada com o modelo norteamericano, em diversos países europeus. Ver, a propósito, CAPPELLETI, Mauro. O controle judicial de constitucionalidade das leis no direito comparado. 2 ed. Porto Alegre: Sergio Antonio Fabris Editor. 1999

${ }^{111}$ Prieto Sanchís assinala, com propriedade, que as Constituições do neoconstitucionalismo, de que são exemplos a Lei Fundamental de Bonn, de 1949, e as Constituições da Itália de 1947, e da Espanha de 1978-, e a brasileira de 1988, incorporam da tradição norte-americana a idéia da supremacia hierárquico-normativa das normas constitucionais, e da tradição européia o vasto conteúdo normativo. Tais Constituições consubstanciamse, pois,
} 
circunstâncias, entre outras, indicam a retirada de uma miríade de matérias do alcance do poder deliberativo ordinário dos poderes constituídos, revelando que o neoconstitucionalismo traz um incremento do nível de rigidez constitucional quando comparado com o constitucionalismo liberal.

Tal fator institucional deve ser associado à evolução que se verificou no plano da hermenêutica jurídica. Refere-se à atribuição de força normativa aos princípios, característica marcante da teoria do direito neoconstitucionalista, ${ }^{112}$ que habilita o juiz, p. ex., a invalidar leis com lastro em normas de alta abstração e conteúdo moral, a respeito das quais grassa profundo desacordo nas sociedades pluralistas contemporâneas. Evidentemente que a soma das características institucionais e teóricas no neoconstitucionalismo reforça a dificuldade contramajoritária $^{148}$ que acomete o Judiciário quando do exercício do controle de constitucionalidade, pois se o só fato de juízes não eleitos afastarem o resultado da deliberação majoritária dos representantes do povo já suscita a alvitrada crítica, que dirá o exercício dessa atividade excepcional com base em normas cuja identificação do seu sentido é dificultada pela sua fluidez e pelas divergências acerca do seu conteúdo moral.

Assim, embora o atual fenômeno de generalização da rigidez constitucional haja atestado a pertinência da tese de que a previsão de direitos fundamentais e da separação de poderes numa Constituição rígida e oriunda de um processo deliberativo superior equilibra os ideais constitucionalista e democrático, faz-se mister reconhecer que as Constituições contemporâneas apresentam um nível de rigidez constitucional mais intenso do que as Constituições-Garantia. Tais considerações dão azo a uma série de advertências relevantes, que serão adiante arroladas à guisa de encerramento, sem qualquer pretensão de tratar analiticamente da questão, já que isto pressuporia uma análise autônoma.

Com efeito, a exaltação das virtualidades da supremacia hierárquico-normativa da Constituição não nos deve conduzir a uma "sacralização" das normas constitucionais, olvidando-nos dos recorrentes casos em que elites valeram-se das supermaiorias necessárias à

numa ousada fusão de tradições constitucionais, que tende a comprimir o âmbito de deliberação das maiorias políticas. V. PRIETO SANCHÍS, Luis. Justicia constitucional y derechos fundamentales.

${ }_{112}$ Alude-se, especialmente, à vertente da Teoria dos Princípios, erigida a partir do seminal magistério de Ronald Dworkin, e desenvolvida por Robert Alexy. V. DWORKIN, Ronald. Levando os direitos a sério. São Paulo: Martins Fontes, 2002; ALEXY, Robert. Teoría de los derechos fundamentales. Madrid: Centro de Estudios Constitucionales, 1997148

A expressão foi consagrada na clássica obra de BICKEL, Alexander M.. The Least Dangerous Branch - The Supreme Court at the Bar of Politics. New Haven: Yale University Press, 1986. 
alteração da Constituição para entrincheirar privilégios, petrificando o status quo. Tal conduta inequivocamente atenta contra a democracia (e, no caso brasileiro, contra a pretensão da Carta de 1988 de promover a justiça social), na medida em que prejudica o direito de o povo ser artífice do seu destino coletivo. A síntese dessas visões distintas acerca das virtudes das normas constitucionais é a adoção de uma perspectiva que, por um lado, não chega ao extremo de considerar que a rigidez constitucional significa, necessariamente, a petrificação da doutrina defendida por um grupo social mais bem articulado, nem confere uma aura de santidade a toda e qualquer norma constitucional, independentemente da aferição do seu conteúdo. Comunga-se, portanto, da concepção de John Rawls de que, caso a atuação contramajoritária do Judiciário se restringir à uma zona de neutralidade política, é dizer, à tutela de princípios que sejam objeto de um consenso sobreposto entre as diversas doutrinas adotadas pelos indivíduos, logra-se obter um modelo que proteja contenha as deliberações de maiorias ocasionais em proteção à dignidade humana, sem colocar em risco o direito de autodeterminação coletiva da geração atual.

A segunda advertência concerne à circunstância de que a indeterminação e a conflituosidade que são inerentes à aplicação dos princípios jurídicos pelo Judiciário deve servir de estímulo para que a doutrina desenvolva elementos de interpretação (v.g.: gramatical, histórico, sistemático e teleológico), princípios instrumentais (v.g.: supremacia da Constituição, interpretação conforme a Constituição, presunção de constitucionalidade, efetividade da Constituição, proporcionalidade, razoabilidade, proteção ao núcleo essencial, os instrumentos de auto-restrição judicial (judicial self restraint), etc.) e de parâmetros de ponderação (v.g.: prevalência prima facie das regras aos princípios, hierarquia axiológica subjacente à Constituição e grau de restrição aos princípios em conflito) que confiram racionalidade e objetividade mínimas à atuação do juiz.

\section{BIBLIOGRAFIA}

ACKERMAN, Bruce. We the people - Foundations. Cambridge: The Belknap University Press, 1991.

. We The People - Transformations. Cambridge: The Belknap University Press, 1998. . The rise of world constitutionalism, in Yale Law School Occasional Papers, Second Series, Number 3, Connecticut, 1997, p. 01/20. 
ALEXY, Robert. Teoría de los derechos fundamentales. Madrid: Centro de Estudios Constitucionales, 1997.

ANDRADE, José Carlos Vieira de. Os Direitos Fundamentais na Constituição Portuguesa de 1976. 2 ed. Coimbra: Ed. Almedina, 2000.

BAYÓN, Juan Carlos. "Derechos, democracia y constitución". In: LAPORTA, Francisco. Constitución - problemas filosóficos. Madrid: Centro de Estudios Políticos y Constitucionales, 2003

BOBBIO, Norberto. Locke e o direito natural. Brasília: Ed. UnB, 1998. . Liberalismo e Democracia. 6 ed. São Paulo: Ed. Brasiliense, 1994.

BICKEL, Alexander M.. The Least Dangerous Branch - The Supreme Court at the Bar of Politics. New Haven: Yale University Press, 1986.

BRITO, Miguel Nogueira. A constituição constituinte: ensaio sobre o poder de revisão da constituição. Coimbra: Coimbra Editora, 2000.

BRYCE, James. Constitutiones flexibles y Constitutiones rígidas. Madrid, 1963

BURDEAU, Georges. Droit Constitutionnel et Institutions Politiques. Paris: Librairie Générale de Droit et de Jurisprudence, 1980

CANOTILHO, José Joaquim Gomes. Direito Constitucional. Coimbra: Almedina, 1992.

CAPPELLETI, Mauro. O controle judicial de constitucionalidade das leis no direito comparado. 2 ed. Porto Alegre: Sergio Antonio Fabris Editor, 1999.

CARRE DE MALBERG. Contribuition a la Théorie Génerale de L' Etat. Paris: Librairie de la Société du Recueil Sirey, 1920.

COOLEY, Thomas. Princípios Gerais de Direito Constitucional nos Estados Unidos da América. Campinas: Russel, 2002

COMPARATTO, Fábio Konder. A Afirmação histórica dos direitos humanos. 2 ed. São Paulo: Ed. Saraiva, 2001.

DAHL, Robert. Democracy and its critics. New Haven: Yale University Press, 1989

DWORKIN, Ronald. Levando os direitos a sério. São Paulo: Martins Fontes, 2002.

ELSTER, Jon. Ulysses and the Sirens - Studies in rationality and irracionality. Great Britain: Cambridge University Press, 1979. 
FIORAVANTI. Maurizio. Constituición. De la antiguedad a nuestros días. Madrid: Editorial Trotta, 2001.

.Los Derechos Fundamentales - Apuntes de la Historia de las Constituciones.. 4 ed.Madrid: Editorial Trotta, 2003

JELLINEK, Georg. Teoría General del Estado. Buenos Aires: Editorial Albatroz, 1973

GINSBURG, Tom. Judicial review in new democracies: constitutional courts in asian cases. USA: Cambridge University Press, 2003.

HARIOU, André. Droit Constitutionnel et Institutions Politiques. Paris: Éditions Montchrestien, 1972

HALL, Hermit L. The Oxford Guide to Supreme Court Decisions. New York: Oxford University Press, 1999.

HOBBES, Thomas. Leviatan - o la materia, forma y poder de uma republica, eclesiastica y civil. Mexico: Fondo de Cultura Económica, 1992.

HOLMES, Stephen. Pre-commitment and the paradox of democracy. In: HOLMES, Stephen. Passions and Constraints - on the theory of liberal democracy. Chicago: University of Chicago Press

HOMERO. Odisséia, Livro XII. São Paulo: Nova Cultural, 2002

LAFER, Celso. A Reconstrução dos Direitos Humanos - Um diálogo com o pensamento de Hannah Arendt. São Paulo: Companhia das Letras, 1988

LASLETT, Peter. Introdução aos dois tratados sobre o governo civil. São Paulo: Ed. Martins Fontes, Trad.: Julio Fischer, 2001

LOCKE, John. Dois Tratados sobre o Governo. São Paulo: Martins Fontes, 2001.

MADISON, James et. al.. O federalista. Campinas: Russell, 2003

MATTEUCCI, Nicola. Contratualismo. Dicionário de Política. vol. 1, 12 ed. BOBBIO, Norberto et. Al. Brasília: LGE ed. e UnB ed..

MONTESQUIEU. Charles de Secondat. The Spirit of Laws. William Benton Publisher: London, 1952.

MERQUIOR, José Guilherme. O liberalismo antigo e moderno. 2 ed. São Paulo: Ed. Nova Fronteira. 
NINO, Carlos Santiago. Introdución al análisis del derecho. 11 ed. Barcelona: Ariel Derecho, 2003

NOWAK, John E.; ROTUNDA, Ronald D. Constitutional law. St. Paul: Thomson West, 2004.

PARAMO ARGUELLES, Juan Ramon. Rousseau, estado de derecho, democracia y derechos. In: PECES-BARBA MARTINES, Gregorio et al. Historia de los derechos fundamentales. Tomo II: Siglo XVIII, Volumen II - La filosofía de los derechos humanos.

PIÇARRA, Nuno. A Separação dos Poderes como Doutrina e Princípio Constitucional - Um Contributo para o Estudo das suas Origens e Evolução. Coimbra: Coimbra Editora, 1989

PECES-BARBA MARTINEZ, Gregório. Curso de Derechos Fundamentales - Teoría General. Madrid: Universidad Carlos III, 1999

PEREZ-LUÑO, Antonio Henrique. Derechos Humanos, Estado de Derecho y Constituición, 5 ed. Madrid: Tecnos, 1995

PRIETO SANCHÍS, Luis. Justicia constitucional y derechos fundamentales. Madrid: Editorial Trotta, 2003.

ROUANET, Sergio Paulo. Mal-Estar na Modernidade. São Paulo: Companhia das Letras, 2001 ROUSSEAU, Jean Jacques. O Contrato Social - Princípios de Direito Político. São Paulo: editora Martins Fontes, 2003

SANCHÍS, Luis Prieto. Justicia constitucional y derechos fundamentales. Madrid: Editorial Trotta, 2003.

SARMENTO, Daniel. Direitos Fundamentais e Relações Privadas. Rio de Janeiro: Lumen Iuris editora, 2004,

Interesses Públicos vs. Interesses Privados na Perspectiva da Teoria e da Filosofia Constitucional. In: SARMENTO, Daniel (org.). Interesses Públicos vs. Interesses Privados: Desconstruindo o Princípio de Supremacia do Interesse Público. Rio de Janeiro: Lumen Iuris, 2005

.Direito adquirido, emenda constitucional, democracia e reforma da Previdência. In: TAVARES, Marcelo Leonardo (org.). A reforma da previdência social: temas polêmicos e aspectos controvertidos. Rio de Janeiro: Lúmen Iuris. 2004

SIEYÈS, Emmanuel Joseph. Qu'est-ce que le Tiers État. Rio de Janeiro: Liber Juris, Rio de Janeiro.

THAYER, James Bradley. The origin and the scope of the american doctrine of constitutional law. Harvard Law Review 129 (1893).

TRIBE, Laurence. American Constitutional Law. New York: New York University Press, 2000 


\section{Quaestio Iuris}

TULLY, James. An approach to political philosophy: Locke in contexts - Ideas in context. Cambridge: Cambridge University Press, 1993

VEGA, Pedro de. La reforma constitucional y la problematica del poder constituyente. 5 reimpresión, Madrid: Tecnos, 2000.

VIEIRA, Oscar Vilhena. A constituição e sua reserva de justiça: um ensaio sobre os limites materiais ao poder de reforma. São Paulo: Malheiros, 1999, p. 53, utilizando-se da expressão de Madison no Federalista, n. 51. Op. cit. 